\title{
A Decade of Economic Reforms in India: the Unfinished Agenda
}

\author{
Nirupam Bajpai \\ CID Working Paper No. 89 \\ April 2002
}

- Copyright 2002 Nirupam Bajpai and the President and Fellows

of Harvard College
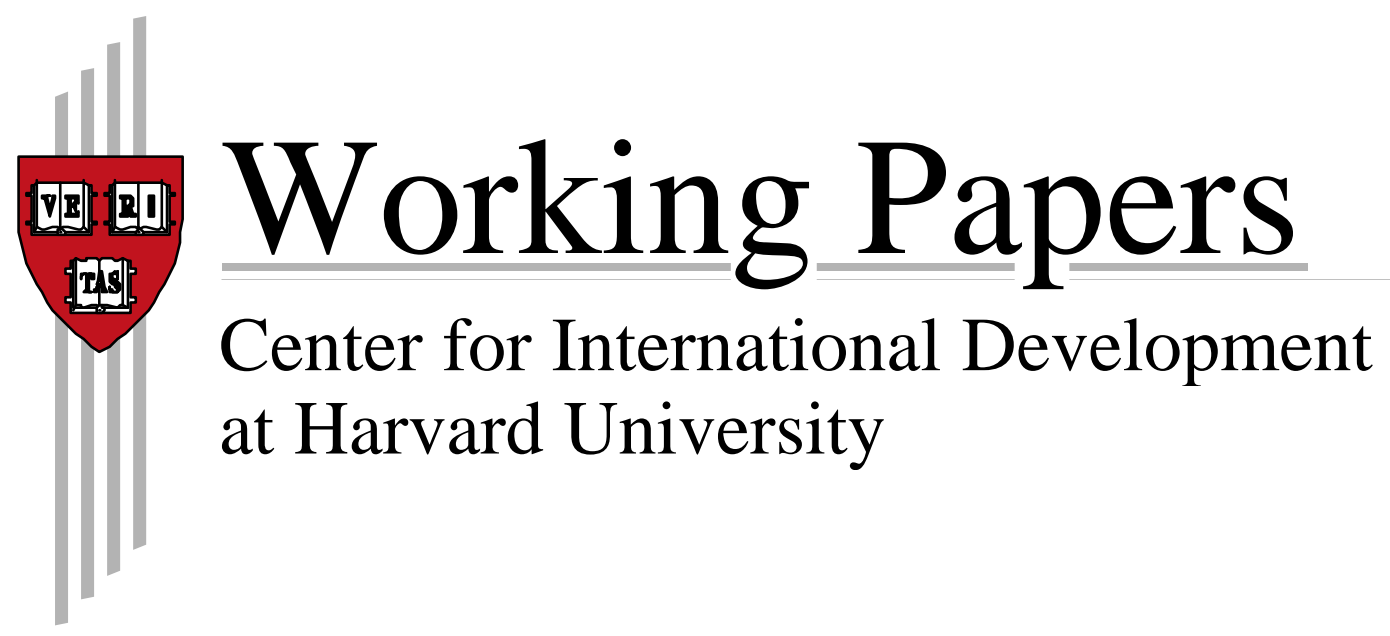


\title{
A Decade of Economic Reforms in India: the Unfinished Agenda
}

\author{
Nirupam Bajpai ${ }^{1}$
}

\section{Crisis and Response:}

In response to a fiscal and balance of payments crisis in1991, India launched a program of economic policy reforms. The program consisting of stabilization-cumstructural adjustment measures was put in place with a view to attain macroeconomic stability and higher rates of economic growth. Some rethinking on economic policy had begun in the early 1980s, by when the limitations of the earlier strategy based upon import substitution, public sector dominance and extensive government control over private sector activity had become evident, but the policy response was limited only to liberalizing particular aspects of the control system. By contrast, the reforms in the 1990s in the industrial, trade, and financial sectors, among others, were much wider and deeper. As a consequence, they have contributed more meaningfully in attaining higher rates of growth. India has gone through the first decade of her reform process. Hence, an assessment of what has been achieved so far and what remains on the reform agenda is in order ${ }^{2}$ Four different governments were in office during the 1990s - the Congress government which initiated the reforms in 1991, the United Front coalition (1996-98) which continued the process, the BJP led coalition which took office in March 1998 and then again the BJP led National Democratic Alliance (NDA) in October 1999 till date. In short, it seems that India's political system is more than ever in consensus about the basic direction of reforms.

As in the case of most developing countries that have liberalized the economy in the last three decades of the $20^{\text {th }}$ century, India's reforms too were preceded by a serious financial crisis. In 1990-91, the gross fiscal deficit of the government (center and states) reached 10 percent of GDP, and the annual rate of inflation peaked at nearly 17 percent in August 1991. Fiscal imbalances in India, which assumed serious proportions since the mid 1980s, had two important facets. First, the outpacing of the rate of growth of revenues by the expenditure growth considerably reduced the resources available for public investment in the economy. The increasing use of borrowed funds to meet current expenditures rendered the latter self-propelling. Second, the increasing diversion of household savings to meet public consumption requirements not only resulted in the expansion of public debt to unsustainable levels, but also reduced the resources available for private investment.

An unprecedented balance of payments crisis emerged in early 1991. The current account deficit doubled from an annual average of $\$ 2.3$ billion or 1.3 percent of GDP during the first half of the 1980s, to an annual average of $\$ 5.5$ billion or 2.2

\footnotetext{
${ }^{1}$ This paper draws on some of the research work that Professor Jeffrey Sachs and I have undertaken on India's reforms over the past few years.

${ }^{2}$ For previous assessments of India's reforms, see Joshi and Little (1996); Alhuwalia and Little (1998); and Sachs, Varshney and Bajpai (1999).
} 
percent of GDP during the second half of the 1980s. For the first time in modern history, India was faced with the prospect of defaulting on external commitments since the foreign currency reserves had fallen to a mere $\$ 1$ billion by mid-1991.

The balance of payments came under severe strain from one liquidity crisis experienced in mid-January 1991 and another in late June 1991. On both occasions, the foreign exchange reserves dropped significantly and the government had to resort to emergency measures, such as using its stocks of gold to obtain foreign exchange, utilization of special facilities of the IMF, and emergency bilateral assistance from Japan and Germany among others. Having resorted to these measures, the government was able to avoid default in terms of meeting its immediate debt service obligations and the financing of imports. Subsequently, the government embarked upon a program of more fundamental economic policy reforms.

\section{Fiscal Consolidation:}

The fiscal deficit of the central government, which stood at 8.3 percent of GDP in fiscal 1990/91, was brought down to 5.9 percent by the end of 1991/92. However, there was a major slippage in 1993-94 when the fiscal deficit bounced back to 7.5 percent of GDP ${ }^{3}$. Since then, the fiscal deficit has witnessed a gradual decline and was placed at 5.5 percent of GDP in 2000/01 and is budgeted at 5.1 percent for 2001/02 (Table 1). A major part of the fiscal deficit, namely, the revenue deficit (revenue expenditure minus revenue receipts) currently running around 3.4 percent of GDP remains the core problem area. Over the 1990s, the revenue expenditure has in fact risen from an already high level of 12.9 percent of GDP in 1990/91 to 13.3 percent in $2000 / 01^{4}$. On the contrary, capital expenditure has gone down substantially from an already low level of 5.6 percent of GDP in 1990/91 to a mere 2.3 percent in 2000/01.Central government total expenditure has gone down from being 18.5 percent of GDP in 1990/91 to 15.6 percent in 2000/01. This reduction, however, has materialized primarily at the cost of cuts in capital expenditures.

Considering the excessive pre-emption of the community's savings by the government, the potential for crowding out the requirements of the enterprise sector, the pressure on interest rates, and rising interest payments on government debt, it is essential to reduce the fiscal deficit still further, and more aggressively, mainly by lowering the revenue deficit. In the absence of substantial fiscal adjustment, neither will the government be able to maintain low inflation, nor will India achieve a path of sustainable high growth. India's overall government spending, (center and states) current around 33 percent of GDP, needs to be brought down substantially as a proportion of national product in order for India to achieve its reform goals of macroeconomic stability and long-term rapid growth (Bajpai and Sachs, 1997a).

\footnotetext{
${ }^{3}$ These ratios to GDP are at $1980 / 81$ prices. With a change in the base year, all ratios in the tables in this paper are at 1993/94 prices.

${ }^{4}$ CMIE Economic Intelligence Service, Public Finance, March 2002.
} 
Keeping in view the fact that the fiscal deficit still remains very high, the process of fiscal consolidation needs to be pursued much more vigorously. According to the Global Competitiveness Report ${ }^{-}$(GCR) 2001/02, India ranks $72^{\text {nd }}$ out of the 75 countries ranked on general government fiscal surplus/deficit as a percentage of GDP in the year 2000. Large and persistent fiscal deficits in India are a serious cause for concern. There are several risks with high fiscal deficits. First, budget deficits could once again spill over into macroeconomic instability. Second, the budget deficits imperil national saving rates, thereby reducing overall aggregate investment, and jeopardizing the sustainability of high growth. The effects of low investment rates on overall GDP growth are not hard to see. Most directly, low levels of public investment have rendered India's physical infrastructure incompatible with large increases in national product. Without an increase in the scale and rate of growth of infrastructure investment, growth rates in India are bound to remain moderate at best. Third, the continuing large budget deficits, even if they do not spill over into macroeconomic instability in the short run, will require higher taxes in the long term, to cover the heavy burden of internal debt. High tax rates will place India at a significant disadvantage relative to other fast-growing countries.

Expenditure reform in India is critical in view of the fact that India's government dissaving (refer to Table 5 for data on public savings) and overall level of government spending remains very high. There is probably little room to cut capital expenditures, in view of the fact that they have already been squeezed significantly. Of course, in the future, it should be the private sector rather than the government to meet most of the enormous infrastructure needs of a growing economy. Still it is hard to imagine that rapid growth can be accomplished with public investment spending by government of less than the current rate relative to GDP. According to the GCR $2001 / 02$, India ranked 66th out of the 75 countries ranked on the overall quality of infrastructure.

Inadequate public investment in the post-reform period had an adverse impact on the economy (Table 5). It led to serious under-investment in critical infrastructure sectors such as electric power generation, roads, railways and ports. For example, the addition to power generation capacity in the public sector during the Eight Plan was only a little over half the target. There were similar shortfalls in capacity creation in roads and ports. These shortfalls would not have mattered if capacity in the private sector had expanded, but this did not happen either. The end result was that total investment in infrastructure development was less than it should have been, leading to large infrastructure gaps. The economy was able to achieve higher economic growth in the post reform years despite inadequate investment in infrastructure because there was some slack in the system, but there can be no doubt that rapid growth will be difficult to sustain in future unless investment in infrastructure can be greatly expanded.

\footnotetext{
${ }^{5}$ The Global Competitiveness Report 2001/02, World Economic Forum and the Center For International Development at Harvard University, Oxford University Press, February 2002. For GCR details and other comparative rankings for India refer to Section VI.
} 


\section{Expenditure Reform:}

Governmental action is needed in reducing expenditure under four major heads of current spending. With respect to internal public debt, there is one important mechanism that could substantially ameliorate the fiscal situation. Privatization of public enterprises could raise significant funds as a percent of GDP, which could be used to buy down the public debt. Not only would the stock of debt itself be reduced, but also the interest costs of servicing the debt would surely decline as the debt stock itself was brought under control. Interest payments account for as high as 4.9 percent of GDP in 2001/02 (Table 3). The cash value of these enterprises vastly exceeds the present value of profit flows that the state now collects on these assets. Public sector profits are dissipated in poor productivity, over manning, excessive public sector salaries, soft budget constraints, and generally poor public-sector management.

For this reason, sales of the enterprises to private sector buyers, if used to buy down the public debt, would yield annual saving in interest costs that far exceed the government revenues that are claimed by virtue of state ownership of the assets. The central government currently has equity holdings in 240 enterprises, 27 banks, and two large insurance companies. This is especially true in view of the fact that many enterprises with significant positive market value are actually loss makers in current cash flow, under state management. While the recent sale of 25 percent equity of VSNL and 33.6 percent of IBP, besides four hotels of the ITDC are very encouraging, the total accrual to the central exchequer from disinvestments in 2001/02 would only be around Rupees 50 billion $^{6}$, roughly about 41 percent of what the 2001/02 budget had estimated to collect. Further spending cuts could come from liquidation of loss-making enterprises that have no positive net market value. Liquidation of these would imply a rise in domestic savings. Of course, saving would be higher if there is salvage value in part or all of some of these enterprises. To capture these savings would require implementation of an exit policy to allow the government to close down these lossmaking enterprises.

Reduction in central government subsidies is another area of expenditure control. Reforms in the current subsidy regime should be undertaken with the objective of reducing the overall scale of subsidies. Moreover, the reforms should help make the subsidies transparent, and use them for well-defined economic objectives. Subsidies should focus on final goods and services with a view to maximizing their impact on the target population at the minimum cost. The key to subsidy reduction lies in phased increase in user charges in sectors, such as power, transport, irrigation, agriculture and education.

Reducing the size of the public administration could also cut government spending significantly, both at the federal and state levels. One way to achieve a reasonable degree of success in this direction might be a freeze on new employment, matched by normal attrition through retirement and death. Existing functions could easily be met through modest improvements in computerization and information

\footnotetext{
${ }^{6}$ Economic Survey, 2001/02, Government of India, Ministry of Finance, p.169.
} 
systems. Obviously, bolder -- if less politically palatable -- solutions could result in even larger savings. While the 2002/03 union budget does announce abolition of nearly 12,200 posts out of the 42,200 identified by the Expenditure Reforms Commission as surplus manpower , one would have to wait and see if indeed this is implemented. We estimate expenditure saving that could be achieved by these cuts to a total of roughly 4.9 percent of GDP over a three-year period for the federal government ${ }^{2}$ (Sachs and Bajpai, 2000). Of course, we would stress that these are approximate. Perhaps these bold cuts could be augmented by 1 or 2 percent of GDP in increased tax collections, though credibility in collecting more taxes would depend firmly on making sharp cuts in major areas of waste.

\section{Tax Reforms:}

While progress has been made in the area of tax reforms, the tax structure in India still remains very complicated with high rates of taxation with regard to both direct and indirect taxes. In the area of personal income tax, the reforms have succeeded in establishing a regime of moderate tax rates, which compare well with other countries. The maximum rate of personal income tax has come down from 56 percent at the start of the reform to 30 percent. The rate of corporation tax on Indian companies, which varied from 51.75 percent to 57.5 percent in 1991-92, depending upon the nature of the company, has been unified and reduced to 35 percent. However, corporate tax rates are still quite high in India despite the reduction announced in the union budget ${ }^{2}$ for foreign companies. Per the GCR 2001/02, India ranked $50^{\text {th }}$ out of a total of 75 countries ranked in the GCR on corporate income tax rate in 2001. Despite these reductions in rates, revenues from personal and corporate taxes have remained buoyant as indicated by the continuing increase in these revenues as a percent of GDP (Tables $3 \& 4$ ). The share of direct taxes in GDP is still too low, but it has increased steadily over time. On the whole, this appears to be an area where the strategy of reform seems to be working fairly well and needs to be continued, with special emphasis on means to broaden the base of income tax payers and much stronger enforcement on tax collection.

While the country has come a long way from being a closed economy to a relatively open one, India still is a highly protected economy by current international standards. In fact, as per the GCR 2001/02, India ranked $74^{\text {th }}$ out of a total of 75 countries ranked in the GCR on average tariff rate (\%) in 2001. Nigeria is the only country having a higher average tariff rate than India. Excise duties are a major source of indirect tax revenue in India and performance in this area has been weak. Ideally, the domestic indirect tax system should have been converted into a full-fledged VAT, which integrates the tax system from manufacturing down to retail sales, creating a self re-enforcing chain of tax compliance. Experience in other countries shows that a shift

\footnotetext{
${ }^{7}$ Budget Speech of the Finance Minister for the year 2002/03, New Delhi, February 28, 2002.

${ }^{8}$ Disinvestment in public sector enterprises, closure of loss-making enterprises, reduced bureaucracy, reduced central power sector undertakings support to state electricity boards, and reduction in subsidies, including PDS and transport.

${ }^{9}$ Central Government Budget for 2002/03
} 
to VAT would help improve revenue generation but this is not possible in India under the present constitutional division of powers, whereby excise duties at the production stage are levied by the Central Government while sales taxes at the wholesale and retail level are levied by the States.

In the absence of VAT, India had introduced a modified VAT (called Modvat) under which credit is given for excise taxes paid on inputs against excise taxes due on outputs thus avoid cascading of excise duties. This system was extended and rationalized during the reforms in various ways. The tax credit facility (Modvat facility) was earlier not available for all products, but now has universal coverage. Earlier, credit was given only for duties paid on inputs but since 1995 it has been extended to duties paid on capital goods. These efforts at rationalizing the excise duty structure were expected to lead to a rising share in the ratio of excise revenue to GDP but in fact excise revenues have declined steadily.

As mentioned before, while it will be necessary to reduce government expenditure by cutting inessential expenditure, at the same time, it is important to increase government expenditure in important areas. In our view, the government needs to give greater attention to, and provide larger resources for, education and health. In the sphere of raising the literacy levels and providing greater access to basic health services, the state governments are required to play a much more enlarged role. On the quality of public (free) schools, India is ranked $62^{\text {nd }}$ in the GCR. Further, looking at the average total years of schooling among population aged 15 and above, India ranked $56^{\text {th }}$ out of 63 countries for which data was available in the GCR.

Both the federal and state governments have a particularly urgent and critical role in spreading literacy and access to primary health care to all the Indians so that they can all participate in a meaningful manner and benefit fully from India's economic transformation. Much higher levels of literacy could be achieved through creative mobilization of new IT approaches, better school attendance, and other policies, all with a clear focus on inclusion of girls and other traditionally disadvantaged groups. The economic and social returns from such an initiative would be huge. Evidence from across the world suggests that high levels of literacy have helped raise growth rates and reduced fertility rates over time. Additionally, the federal government needs to undertake aggressive public health campaigns to address major infectious diseases (pneumonia, diarrheal diseases, and malaria) and especially the incipient AIDS epidemic, which now threatens India with tens of millions of cases unless properly addressed (Bajpai and Sachs 2000).

\section{Controlling Inflation:}

The first four years of the 1990s registered double-digit inflation based on the wholesale price index, (WPI) with a 13.6 percent peak reached in 1992-93 (Table 2). High fiscal deficits, devaluation of the rupee, periodical increases in administered prices (especially in official procurement and issue prices of food grains), weather 
conditions, shortages of some commodities of common consumption, and large money creation due to acquisition of foreign currency reserves contributed, in varying degrees, and at different points of time, to the relatively higher inflation in the first half of the 1990s. However, from 1995/96 onwards, there has been a continuous deceleration and the average inflation for the period $1996 / 97$ to $2000 / 01$ is by far the lowest since the mid-1950s in terms of the 52- week average. The point-to-point average inflation rate for this period is the lowest since the early 1960 s.

The developments in the economy since 1996 have been conducive to a decline in the inflation rate. Importantly, on the demand side, there has been a noteworthy change in the source of reserve money creation. Over the decades, monetization of the budgetary deficits by the Reserve Bank of India (RBI) had accounted for a predominant part of reserve money creation and the resultant growth, often excessive, in money supply. Since 1996/97, monetization of the budget deficit has declined sharply. During 1993 and 1994, primary liquidity was created mainly in the process of the RBI accumulating foreign currency reserves due to large inflows of foreign investment. With interest rates rising in most industrial economies, the impact of the Mexican crisis and the steps taken by the government of India to regulate the recourse of Indian industry to foreign financial markets, these inflows moderated.

As government's borrowing is still very high and demand for commercial credit expected to pick-up pace, satisfying both the government and enterprise sectors will pose a difficult challenge to the monetary authorities who would like to restrain money growth to keep inflation under check. However, as pressures for reserve money creation abate, the RBI should be in a better position to balance the objectives of economic growth and moderation in prices. Satisfactory production of both food and non-food crops should keep the inflationary expectations subdued. Supply side management would be facilitated by large food stocks 10 and high foreign exchange reserves 1 Table 2). Releases of food stocks into the open market and through the public distribution system should keep cereal prices under check. The public stocks can also be used for food-for-work programs. Commodities such as sugar, edible oils and cotton, which were in short supply in the mid-1990s, have already been placed on the open general license and are thus freely importable.

\section{Reforms in the Trade and Foreign Investment Regimes:}

The set of policies regarding the external sector including devaluation of the rupee, making the rupee convertible on current account, liberalization of the trade regime, allowing imports of gold, encouraging foreign direct investment (FDI) and technology inflows, opening the capital market to portfolio investment by foreign institutional investors (FIIs), and permitting domestic companies to access foreign capital markets have brought about a dramatic turnaround and steady progress in the

\footnotetext{
${ }^{10} 58$ million tonnes as of January 2002.

${ }^{11} \$ 46.56$ billion as of January 2002, providing cover for about 10 months of estimated imports in 2001/02.
} 
balance of payments. The export-import ratio improved from 66.2 percent in 1990/91 to 75.8 percent in 2000/01. Merchandise exports rose from $\$ 18.4$ billion in 1990/91 to $\$ 44.8$ billion in 2000/01. Non-oil imports over the same period rose from $\$ 21.8$ billion to 43.6 billion, but the current account deficit remains at less than one percent of GDP (Table 6).

\section{Trade and Exchange Rate Policies:}

The past import substitution policies characterized by pervasive quantitative restrictions on imports and steep customs duties have undergone change. Quantitative restrictions on imports of capital goods, intermediates and raw materials have been abolished. These, however, survive in the case of final consumption goods though gradual relaxation is underway. Customs duties have been reduced gradually. The maximum duty rate has declined from 250 percent to 30 percent. Tariffs on most capital goods, plants and machinery now stand at 20 percent as against $80-85$ percent earlier. Duties on intermediates and raw materials have also been lowered. The process is still continuing so that the Indian tariff structure would be in line with that in most other developing countries, though it has been rather slow. Liberalization of trade has reduced costs of Indian industry, relieved production bottlenecks, promoted technology up gradation and export orientation and, encouraged competition. The gradual trade liberalization has enabled domestic industry to adjust to the new situation. Though apprehensions persist in some quarters about external competition, the Indian industry has generally accepted the need for, and logic of, the ongoing change.

The removal of quantitative restrictions and reduction in tariff levels implemented over the 1990s would not have been possible but for parallel changes in exchange rate policy. The rupee was devalued in July 1991 by 24 percent as part of the initial stabilization program, and a dual exchange rate was introduced briefly from March 1992 to March 1993. In March 1993, the dual exchange rate was unified and the unified rate was allowed to float. The flexible exchange rate regime has worked reasonably well with the exchange rate responding to market conditions while the RBI intervenes periodically through foreign exchange sales and purchases or through monetary fine-tuning to maintain orderly market conditions. Exchange rate management has avoided the danger of excessive rigidity and also the opposite dangers of overshooting with associated loss of confidence. Although there is no declared real effective exchange rate target, the system has worked in a manner to preserve the advantageous real exchange rate achieved in the early years of the reforms.

Motivated by the success of Chinese Special Economic Zones (SEZs), Shannon Free Trade Zone in Ireland and the like, the Government of India introduced SEZs in India through the Export/Import Policy of 2000. Since then approval has been given to establish twelve SEZs in the following nine states: Gujarat, Orissa, Karnataka, Maharashtra, Tamil Nadu, Madhya Pradesh, West Bengal, Uttar Pradesh, Andhra Pradesh. Notably Positra SEZ in Gujarat, Gopalpur SEZ in Orissa and Nanguneri SEZ in Tamil Nadu are being implemented with private sector participation. This new policy has been introduced with a view to provide an internationally competitive and hassle 
free environment for exports. Units may be set up in SEZ for manufacture, trading, reconditioning, and repair or for service activity. All the export/import operations of the SEZ units will be on self-certification basis. The units in the Zone have to be a net foreign exchange earner but they shall not be subjected to any pre-determined value addition or minimum export performance requirements. Sales in the Domestic Tariff Area by SEZ units shall be subject to positive foreign exchange earning and on payment of full Customs duty. The policy provides for setting up of SEZs in the public, private, joint sector or by State Governments. It was also envisaged that some of the existing Export Processing Zones would be converted into Special Economic Zones.

In a major initiative to boost export-led growth, the new five-year Exim Policy of 2002-07 has lifted all quantitative restrictions on exports, and announced more incentives for SEZs and schemes like Duty Entitlement Pass Book (DEPB), advance license, and Export Promotion Capital Goods (EPCG). The policy also provides an incentive package for the hardware sector, simplifies procedures to reduce transaction costs besides adopting new commodity classification for imports and exports. Coterminous with the Tenth Five-Year Plan, the policy comes a year after the quantitative restrictions were dismantled on imports.

With the lifting of quantitative restrictions on exports, the policy has made a paradigm shift on its focus from import-liberalization to export-orientation. In an important decision to make SEZs globally competitive, the overseas banking units (OBUs) would be permitted to be set up in these zones for the first time in India. These units would be virtually foreign branches of Indian banks but located in India. These OBUs would also be exempt from the normal Reserve Bank of India regulations like the cash reserve ratio and statutory liquidity ratio. They would give the SEZ units access to international finance at global rates.

India's balance of payments has improved considerably since the deficit in the invisible account in the early 1990s has been converted into a surplus as a marketdetermined exchange rate of the rupee has encouraged inward remittances through legal channels (Table 6). There has been an unprecedented build up of foreign currency reserves during the second half of the 1990s. The build up of foreign currency assets of the RBI, which stood at $\$ 46.5$ billion as of January 2002, reflect the steep decline in the current account deficit as well as large net capital inflows. The composition of these inflows has changed significantly towards equity and away from debt. External assistance, external commercial borrowing, IMF loans, and non-resident Indian (NRI) deposits declined progressively from 85.8 percent of net capital inflows in 1990-91 to 40 percent in 1993-94 and further to 23 percent in 1999/00.

The improvement in the balance-of-payments has enabled the government to substantially reduce the growth of external debt. The debt-GDP ratio declined steadily from the high of 38.7 percent in March 1992 to 22.3 percent in March 2001 (Table 7) and further to 21 percent at the end of September 2001. Similarly, the debt service ratio declined from a peak level of 35.3 percent of current receipts in 1990/91 to 17.1 percent in 2000/01. The short-term debt declined from $\$ 8.5$ billion in March 19991 to $\$ 3.4$ 
billion in March 2001, representing a decline in the share of short term to total debt from 10.2 percent to 3.5 percent. Similarly, the proportion of external commercial borrowings and costly NRI deposits in total debt has also declined. The share of concessional debt in total external which was steady around 45 percent during the first half of the 1990s, declined to 36 percent in March 2001.

\section{Foreign Investment Policy:}

The foreign investment policy was reformed and accordingly foreign investment was actively sought. Both foreign direct investment and portfolio flows have been encouraged in the post-reform period with some positive results in both cases. The process of approving FDI was expedited by providing a window of automatic approval of FDI. Foreign investment proposals, which are not eligible for the automatic route, can obtain approval from the Foreign Investment Promotion Board (FIPB). As a result, inflows of foreign investment (FDI, foreign institutional investment, (FII) and Euro equities) increased from a mere $\$ 103$ million in 1990/91 to $\$ 4.1$ billion in 1993-94 to further to $\$ 5.0$ billion in 2000/01 (Table 8). Approvals for FDI have witnessed sharp increases too. The total FDI approved between 1991 and 2001 amounts to $\$ 56.2$ billion, against just under $\$ 1.0$ billion approved during the previous decade. However, the actual FDI inflows have been much smaller relative to the approvals. Total inflows between 1991 and 2001 were placed at 17.9 billion, about 31.8 percent of the total approvals. FDI inflows rose from \$129 million in 1991-92 to \$1314 million in 1994-95 and further to $\$ 2339$ million in $2000 / 01$.

Expeditious translation of approved FDI proposals into actual investment require more transparent sectoral policies, bidding and selection procedures, and a drastic reduction in time-consuming redtapism 12 . The states are becoming increasingly interested in attracting both domestic and foreign investment and should expedite their decision-making processes, especially for provision of land, electricity, water and other infrastructural services to investors. Infrastructural projects on which survey and project work has already been done could be offered to prospective investors.

With the initiation of economic reforms in 1991, the role of private investment has acquired a great deal of significance. Indian states are now in competition with one another to attract private investment, both domestic and foreign. Within states, the flow of investment has tended to be skewed in favor of the urban areas. State-level data on FDI approvals suggest that the relatively fast growing states have tended to attract higher levels of foreign direct investment. The top five states that received the highest inflow of FDI in the country, per June 2001 data, were Tamil Nadu (29.9 percent of the total inflows), Maharashtra (21.7 percent), Delhi (19.8 percent), Andhra Pradesh (13.3

\footnotetext{
${ }^{12}$ Based on a study of 1099 manufacturing companies, spread across ten large states in India, a CIIWorld Bank study found that firms in India spent close to $16 \%$ of management time in dealing with government and other sundry officials as against $9 \%$ in China, $8.3 \%$ in the transition economies of Eastern Europe and just $4.3 \%$ in Latin America.
} 


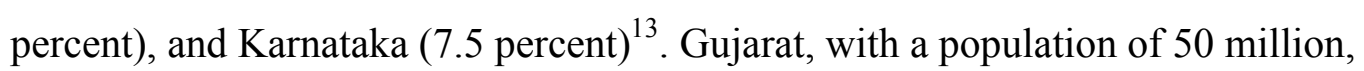
received over a fifth of domestic private investment proposals, whereas Bihar with a population of 83 million barely managed a share of 5 percent of such proposals. Maharashtra and Gujarat account for 37 percent of total investment proposals, while Bihar, Madhya Pradesh, Orissa, Rajasthan and Uttar Pradesh, taken together, were able to attract only 26 percent of investment proposals.

Following the Mexican crisis questions were raised whether India could face similar problems due to volatility of some of the capital inflows. Though the two cases are not comparable (India's current account deficit of less than one percent of GDP and short-term debt at 3.4 percent of total external debt are way below the Mexican current account deficit of 8 percent of GDP and short-term to total external debt proportion of over 30 percent) it is important for India to persist with sound macro-economic policies, avoid overvaluation of the rupee, maintain a reasonably high level of foreign currency reserves to cushion disruptive outflows, and encourage FDI. Of the non-debt creating inflows, priority should attach to FDI, which is long-term in character and also brings technology, management and marketing inputs. The authorities are striving to pursue these policies. Pending further improvement in the macroeconomic situation, they have adopted a cautious approach to the question of the rupee's convertibility on the capital account.

As economic growth acquires further momentum and the investment-saving gap widens, equity inflows through global depository receipts (GDRs) and Euro-convertible bonds could be further encouraged without triggering inflationary pressures. Over dependence on volatile FII should, however, be avoided. India's balance of payments is now underpinned by fairly sound exchange rate and trade policies as well as substantial foreign exchange reserves, and can be regarded as eminently viable over the medium term. The fiscal position, however, needs much more improvement. Inflation is likely to stay at low levels. All this should presage sustainable economic growth in the coming years provided, of course, the saving and investment picture remains satisfactory.

\section{Reforms in the Industrial Policy Regime:}

Industrial licensing was a major instrument of control under which central government permission was needed for both investment in new units (beyond a relatively low threshold) and also for substantial expansion of capacity in existing units. Licensing was undoubtedly responsible for many of the inefficiencies plaguing Indian industry. In a series of steps, licensing was abolished for all except 7 industries viz. alcoholic beverages, sugar, cigars and cigarettes, electronics, aerospace and defense products, hazardous chemicals and pharmaceuticals. The special permission needed under the Monopolies and Restrictive Trade Practices (MRTP) Act for any investment by the so-called "large houses" which was an additional instrument of control over large houses, in addition to industrial licensing was also abolished. Its stated objective

\footnotetext{
${ }^{13}$ Secretariat for Industrial Approvals (SIA) Newsletter, July 2001, Ministry of Industry, Government of
} India. 
was to prevent "concentration of economic power" but in practice it only served as another barrier to entry, reducing potential competition in the system. Abolition of these controls has given Indian industry much greater freedom and flexibility to expand existing capacity, or to set up new units in a location of their choice, thus increasing the pressure of competition as well as the ability to face competition.

With the opening up of the Indian economy, the country's information technology industry has been the biggest beneficiary. Between 1995 and 2000, the Indian IT Industry recorded a CAGR of more than 42.4 percent. Software continues to contribute a major portion of the Indian IT industry's revenues. India's exports of computer software beat global recession in 2001-2002 (April-March) to grow by a

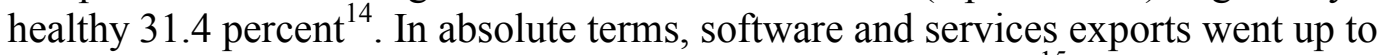
$\$ 7.875$ billion in 2001/02 as against $\$ 5.978$ billion in $2000 / 01^{15}$. The steady growth in exports of software is the combined effect of software giants setting up bases in India to meet their global software requirements in the aftermath of September 11, gradual market penetration that India is making in the non-traditional markets like the EU, Australia, Japan and China, and the increased receivables from IT enabled services like back office operations.

India's exports of electronics hardware grew by 13.6 percent in 2001/02 to $\$ 1.183$ billion from $\$ 1.041$ billion in $2000 / 01$. The IT manufacturing industry has over 150 major hardware players supported by over 800 ancillary units and small time vendors engaged in sub-assemblies and equipment manufacturing. The combined export of software and services, and electronics hardware registered a growth of 28.7 percent in 2001/02. In absolute terms, India's overall IT exports grew to $\$ 9.04$ billion in 2001/02 from $\$ 7.019$ billion in 2000/01. In 1999/00, more than 185 of the Fortune 500 companies outsourced their software requirements to Indian software houses. India's software industry shows the clustering of the software companies in three distinct areas: the southern states specifically Tamil Nadu (Chennai, Madurai, Coimbatore and Trichy), Karnataka (essentially confined to Bangalore), and Andhra Pradesh (essentially confined to Hyderabad), in the west, Maharshtra (Mumbai and Pune), and in the north, Delhi, Noida and Gurgaon. Software companies located in these regions account for almost the entire software and services exports of the country, highest number of firms and employment in the sector.

\section{Public Sector Policy:}

Many areas previously reserved for the public sector have been opened up to the private sector. Although its share has declined in the past ten years, the public sector still accounts for 25 percent of India's GDP, 31 percent of capital investment and 17 percent of the final consumption expenditure in the country. At the start of the reforms 18 important industries, including iron and steel, heavy plant and machinery, telecommunications and telecom equipment, mineral oils, mining of various ores, air transport services, and electricity generation and distribution, were reserved for the

\footnotetext{
${ }^{14}$ Estimates of the Electronic and Computer Software Export Promotion Council (ESC).

${ }^{15}$ This represents $13.3 \%$ of India's manufacturing exports.
} 
public sector. This list has been reduced to 6, covering industries as arms and ammunition, atomic energy, mineral oils, atomic minerals and railway transport. Because of this liberalization, private investment including foreign investment has flowed into areas such as steel, telephone services, electricity generation, petroleum exploration development and refining, coal mining and air transport, none of which would have been possible earlier because of public sector reservation. Part of the government equity in selected public sector enterprises is being disinvested $\frac{6}{6}$. While such disinvestment helps reduce the fiscal deficit, it does not indicate a change in management as government intends to remain a majority stakeholder in public sector enterprises.

Public sector reforms have done little in the cases of units that have been loss making. These units have been making losses for a very long period of time and are very unlikely candidates for revival. The successive governments have ruled out closure of these units and decided instead that the scope for reviving each unit would be carefully examined and only those units where revival was found to be economically feasible would be revived while others would be closed down. Many sick public sector units have been referred to the Board for Industrial and Financial Reconstruction (BIFR) for rehabilitation or, where necessary, for winding up. The latter option has been rarely exercised. The public sector is still hamstrung by excessive government and bureaucratic controls. The option of privatization has not yet been seriously considered. Several public sector units have been identified as fit for closure through this process, and subsequently the government has even decided on closure in many cases, but no unit has been actually closed because the decision has been challenged in the courts by labor unions.

An important area where domestic liberalization has made very little progress is the policy of reserving certain items for production in the small-scale sector. The policy "protects" small-scale units by barring the entry of larger units into reserved areas. It also prevents existing small-scale units from expanding beyond a maximum permissible value of investment in plant and equipment. India is unique in adopting reservation for small-scale producers and the policy obviously entails efficiency losses and imposes costs on consumers. Several committees have recommended various degrees of dilution of the reservation policy. An Expert Committee on Small Enterprises set up in 1995 has recommended that reservation should be completely abolished and efforts to support small scale producers should focus instead on positive incentives and support measures. None of the governments in the post-reforms period has been inclined to accept a drastic re-orientation of policy along these lines.

The present regulations for retrenchment of surplus labor are far too rigid. While the government has made some progress on this front by proposing to allow

\footnotetext{
${ }^{16}$ Between 1991/92 and 2001/02, the total disinvestment proceeds have totaled Rupees 253 billion out of a targeted Rupees 660 billion. During 2002/03, the government has listed strategic sales of oil refiners BPCL and HPCL, petrochemical firm IPCL, Shipping Corporation of India, carmaker Maruti and National Aluminum Company as a few of its big ticket sell-offs.
} 
companies with no more than 1000 employees 7 to retrench labor without prior permission of the government, but this amendment to the Industrial Disputes Act (IDA), 1947, is yet to get Parliamentary approval. Similarly, industrial units require government permission before they can close down and such permission is rarely secured. There has been no progress whatsoever on putting in place an exit policy for firms. In this context, it is noteworthy that while the industrial policy reforms in India have removed virtually all the entry barriers that had existed prior to 1991, however, not allowing firms to exit, if their business conditions so demand, is an entry barriers in itself.

\section{Reforms in the Financial Sector:}

India's financial system has vast geographical and functional reach, capacity to mobilize savings, institutional diversity, and large trained manpower. However, over time, the system has developed weaknesses due to state ownership of bank's and insurance companies, its rapid expansion, externally induced constraints on bank profitability, an over-regulated interest rate regime, and internal organizational deficiencies. Profitability in the banking sector has been very low and some banks have become financially weak. The reform of the banking sector has only addressed these problems partially. It has however sought to develop the money market as well as a secondary market in long-term government debt.

Very high statutory liquidity requirements threygh which banks are compelled

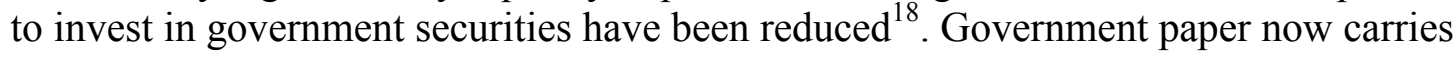
market-clearing rates. There is only one ceiling rate on term deposits prescribed by the RBI. Interest rates on money market instruments have been freed. With government securities now carrying market rates, the basic requirement for developing a secondary market in such paper has been met. Institutions and fora have been created to help develop trade in money and long-term debt markets. To improve the working of banks, a strong prudential regime regarding capital adequacy, income recognition, loan-loss provisions and transparency of accounts has been established. Profitable banks have been permitted to access the capital market to augment their capital.

Commercial banks are increasingly entering new businesses such as merchant banking, underwriting, mutual funds and leasing, usually through subsidiaries. Efforts are on for expediting computerization of bank operations. To enhance competition, many new private sector banks, including some more foreign banks, have been allowed entry into the market. RBI's supervision over commercial banks and other financial institutions including non-bank financial companies has been strengthened. One of the critical areas where banking sector reforms have not progressed relates to government control over public sector banks. Public sector ownership imposes several constraints including limitations in methods of recruitment and promotion and restrictions on the salaries they can pay. Public sector banks are also burdened by standards of public

\footnotetext{
${ }^{17}$ Prior to this proposed change, firms with no more than 100 employees were only permitted to retrench labor without governmental permission.

${ }^{18}$ Indian banks must maintain $25 \%$ of their demand and time deposits in government securities.
} 
accountability, which may be inconsistent with the degree of flexibility needed for commercial decision-making. The Committee on Banking Sector Reforms has recommended that the government's equity holding should be reduced to 33 percent. However, no action on this recommendation has been taken so far.

Over the last two decades, the capital market has grown phenomenally in terms of capital raised, listed companies, trading volumes, market capitalization, and investor base. The number and diversity of market intermediaries - merchant banks, underwriters, custodians, share registrars and transfer agents, mutual fund, rating agencies etc. - have grown rapidly. There are 23 stock exchanges. The Over-the Counter Exchange of India (OTCEI) and the National Exchange have screen based trading and are developing a nationwide reach. The capital market has been liberalized. Corporates are now free to issue capital and price their issues. FIIs (about 280 in number) have been permitted to invest in the Indian market and about 80 of them are quite active. Many Indian companies are accessing foreign markets for raising equity and debt finance.

The regulation of the primary and stock markets as well as of stock exchanges and market intermediaries has been strengthened through the establishment of the Securities and Exchange Board of India (SEBI). SEBI is trying to control insider trading, regulate large acquisition of shares, and improve the trading practices in stock exchanges. It has been able to revamp the governing boards of stock exchanges, which were predominantly the domain of the broker community. Though the primary market has grown dramatically, the stock market infrastructure, practices and procedures are relatively inadequate and slow. Many market intermediaries also lack sufficient capacity to handle growing business and paper work. Share transfers take considerable time. A major challenge is to expand the market infrastructures, upgrade technology, and establish institutions and practices for reducing paper work and delays.

Apart from the National Exchange and OTCEI, the Bombay Stock Exchange too has screen based trading. Measures are also underway to improve clearing and settlement procedures and to establish a national depository system with a view to moving towards scrip less trading in due course. This would require several changes in existing laws. Though it will take considerable time to achieve a desirable level of reform of the financial sector, some progress has been made. Based on the recommendations of the Committee on Reform of the Insurance Sector, the government has opened up the insurance industry to domestic and foreign companies with a view to introduce competition in insurance industry, which, for some decades, had been a government monopoly.

\section{India's Business Environment: Comparative Survey Results from GCR 2001/02}

GCR 2001/02 carried a survey of business leaders in 75 countries of the world, to explore the comparative business environments of the major economies. The GCR focuses on two distinct but complementary approaches. The first one is a growth competitiveness index, (GCI) which focuses on global competitiveness as "the set of 
institutions and economic policies supportive of high rates of economic growth in the medium term." The second one is a current competitiveness index, (CCI) which focuses on microeconomic indicators to measure the "set of institutions, market structures and economic policies supportive of high current levels of prosperity," referring mainly to an economy's effective utilization of its current stock of resources. The survey results are combined with other quantitative data (e.g. objective measures of infrastructure, saving rates, financial market depth, educational attainment, etc.) to produce an overall assessment of international competitiveness, which the study defines as the ability to achieve rapid growth over the medium term.

In the $2001 \mathrm{GCR}$, India ranks a relatively disappointing $57^{\text {th }}$ out of 75 countries in growth competitiveness, slipping below from the rank of $48^{\text {th }}$ in the 2000 Report. On current competitiveness, India ranks $36^{\text {th }}$ in 2001 , little change from the rank of $37^{\text {th }}$ in the 2000 Report. Notable competitive advantages for India include large availability of scientists and engineers, strong potential for "Catch-up" growth, easy access to credit, low exchange rate premium, strong IT training and education, local availability of information technology services, and government success in ICT promotion, quality of management schools, among others (Table 9).

There are, however, many more competitive disadvantages. Notable among these are: lack of access to foreign capital markets, high average tariff rate, stringent hiring and firing practices, high government deficit, extensive distortive government subsidies, permits and time taken to start a firm, large-scale irregular payments in tax collection and government procurement etc. The areas of weakness point implicitly to the most urgent points of the reform agenda. First, despite the importance of the stock exchange, India's financial markets are deficient. The overall sophistication of the financial system is low. Venture capital, which is key to the start up of new industries, is particularly weak. Second, administrative regulations have strongly constrained business activities (the license Raj continues); state subsidies have inappropriately been protecting old industries; the civil service is unduly politicized; and tax evasion is rampant.

Third, and perhaps most strikingly, the quality of infrastructure is abysmal. This is true in all areas: roads, ports, power, and telecomms. For instance, India ranked 69 th out of the 75 countries ranked on telephone lines per 100 inhabitants; $73^{\text {rd }}$ on road quality outside of major cities; $57^{\text {th }}$ on port facilities and inland waterways; and $47^{\text {th }}$ on

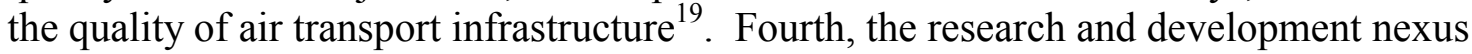
is very weak, with little collaboration between business and academia, and little success in commercializing or adopting new technologies. This poor outcome is ironic in view of the praise for India's science and engineering prowess. Fifth, labor markets are ineffective, perhaps the most ineffective in the world. Put briefly, India shows the advantages of a vast labor force with a skilled engineering and scientific community. It also shows, however, deficiency in both the hard infrastructure, such as roads, ports, and power, as well as the soft infrastructure of public administration, labor market practices, and financial market depth.

\footnotetext{
${ }^{19}$ For details on the investment required in each of these sectors, refer to the India Infrastructure Report.
} 


\section{The Unfinished Reform Agenda:}

The step-up in India's growth rate in the 1980s was partly due to allocative efficiency gains arising from the rather limited deregulation and halting liberalization of only a few aspects of the then prevailing control regime. The continuing structural change in industrial, trade and financial areas, among others, is much wider and deeper and has contributed more meaningfully to higher productivity of the economy. This reinforces the probability of the country registering sustained high levels of economic growth. Indeed, there is potential for growth of 7-8 percent per year (Bajpai 2001). It is necessary to move swiftly to complete many of the reforms, which are now underway. Examples of such continuing reforms are the reduction in protection levels, continuing reforms in banking, sector, product de-reservation for the small-scale industry, decontrol of prices, such as petroleum, reform of the power sector and so on. Among other things, sustaining higher rates of economic growth would require a more vigorous pursuit of economic reforms at both the federal and state levels.

Significant reduction of fiscal deficit is the first order of business. Unless substantial fiscal consolidation is achieved, in our view, continued fiscal deficits pose India's greatest risk to future destabilization. Despite several years of fiscal consolidation effort, large and persistent fiscal deficits remain. India's overall government spending, currently around 33 percent of GDP (center and states together) will need to be brought down substantially as a proportion of national product in order for India to achieve its reform goals of macroeconomic stability and long-term rapid growth. Government dis-savings at the federal and state levels need to be reduced through cuts in, and refocusing of, explicit and implicit subsidies, stricter control of non-developmental expenditure, improvement in the tax ratio through deepening reform of the indirect tax regime and stronger tax enforcement. Lower fiscal deficits will help move towards a regime of low interest rates, which, with efficient financial intermediation, can give a boost to private sector investment.

Privatization of India's state-owned enterprises (SOEs) is critical. Many of the SOEs are inefficient and loss-making firms. These firms tend to be protected by grants of state monopoly, especially in areas of finance, such as commercial banking and insurance, and infrastructure, in areas such as telecommunications, port facilities, and road building. An end to the state monopolization of these sectors is crucial to permit new, privately owned firms to introduce competition and higher productivity into these sectors. Privatization of these enterprises is also desirable in most cases, since the government has no particular comparative advantages in running these enterprises, and may severe disadvantages (especially the politicization of key investment and employment decisions of the enterprises).

Reforms to further opening up of the economy to trade and FDI are crucial if India is to sustain high rates of economic growth. India's average tariff rate of 27 percent vastly exceeds the average tariff rates of the other economies. India also displays continuing high barriers to foreign direct investment in contrast to most of the fast-growing Asian economies. While it is true that not all of East Asia relied heavily 
on foreign direct investment to achieve rapid growth: Japan and Korea are the two main exceptions. But most of the region, especially in Southeast Asia, has relied heavily on FDI (Bajpai and Sachs, 1997b), and the East Asian countries tend to have much simpler rules for FDI approvals than are now in place in India.

If India has to become an attractive destination for FDI and a major platform for labor-intensive manufacturing exports, reforms in India's labor laws and exit policies are extremely essential. China's experience suggests that while workers in the Chinese state sector are accorded generous job guarantees, workers in the non-state sector do not receive guaranteed employment. By contrast, in India, workers in both the public and the private sector, once employed, cannot be laid off without governmental permission. As a result of liberal hiring and firing policies in China, there has been rapid growth of employment, since firms can hire workers without fear of being stuck with unwanted labor in the future due to restrictions on dismissals. Formal sector employment in China has increased dramatically, from 95 million in 1978 to 158.5 million in 2000. India, by contrast, has experienced a meager increase from 22.9 million in 1978 to 27.9 million in 2000, of which 19.3 million are employed in the public sector ${ }^{20}$ Similarly, reform to put in place an exit policy for firms is significant in the Indian context. An exit policy needs to be formulated such that firms can enter and exit freely from the market. While the policy should recognize the need and potential merit of certain safeguards, if wrongly designed and/or poorly enforced it would turn into a barrier that may adversely affect health of the firms.

India has so far made little progress in commercializing the key infrastructural sectors. In power, for example, most electricity continues to be a public-sector monopoly, run by state electricity boards (SEBs). The SEBs are responsible for generating and distributing power, setting tariffs, and collecting revenues. Almost all of the SEBs make losses and some are even unable to pay for coal or the power they purchase. This is due to the fact that SEBs implement social subsidy policies of state governments leading to inefficient patterns of energy consumption, and even to nonrecovery of their own costs. Also, there is considerable theft of power from the distribution networks. SEBs had accumulated dues of Rs. 414 billion, with interest amounting to Rs. 157 billion, as of February 2001 21. Tariff reform, i.e. higher prices actually collected on electricity use, is the first order of business. Privatization of power generation, and the conversion of SEBs from electricity providers to market regulators would come next. Power capacity will not be expanded until the SEBs are fundamentally overhauled or eliminated. Even private power projects currently are expected to sell their electricity to the SEBs as their only power purchaser, so that the

\footnotetext{
${ }^{20}$ A mere $4.6 \%$ of India's working-age population of around 600 million is employed in the formal sector.

${ }^{21}$ In March 2002, the federal Government approved a scheme of one-time settlement of the outstanding dues of the SEBs in order to ensure timely payment of dues by SEB to central public sector undertakings. The scheme includes waiver of $60 \%$ of the surcharge/interest on delayed payments, for states participating in the scheme. The rest of the dues amounting to the full principal amount, as well as the remaining $40 \%$ of the surcharge/interest would be securitized through bonds issued by the respective state governments.
} 
bankability of private sector power projects depends fundamentally on the financial health of the SEBs.

There is no doubt that geography heavily influences economic performance. Both in China and to a lesser extent in India, the real economic success has come in the coastal provinces/states, which can take advantage of export-led growth (Sachs, Bajpai and Ramiah, 2002). The interior has done much less well. Refer to Table 10 for poverty ratios at the state level in India with urban rural classification. GDP growth in the hinterland has lagged behind the coastal states by several percentage points per year. There is a vast amount of economic reform that can be carried out to improve conditions in rural India, especially in the Gangetic valley. There is no reason for expensive and counter-productive charity for the northern states, and still less any case for holding back the fast-growing coastal regions. In India, Tamil Nadu, Maharashtra and Gujarat have the potential to grow as the fastest growing Chinese coastal provinces of Fujian, Zhejiang and Jiangsu.

Perhaps the key step in the Gangetic plain is to improve the most basic infrastructure so that the vast rural populations can take part in more rapid national economic growth. They will do so through increased exports to coastal states, and greatly improved productivity for local production. We should stress that while China's hinterland has lagged behind the coastal regions, the Chinese hinterland too has enjoyed rapid economic growth. The state governments need to adopt a strategy for rural India, in which there will be a reliable infrastructure supplied at commercial prices rather than given for free. The government's commitment, both at the national and state level should be that every village will be assured at least clean water, a road to the regional market, reliable power, and minimal telephone service; but that every village will be responsible for covering the commercial costs of those services on a normal user-fee basis. In particular, Bihar, Uttar Pradesh, and Orissa are in desperate need of reform.

Bihar is the most underdeveloped state of India, perhaps followed by Uttar Pradesh ${ }^{23}$. These states are land locked and have very high birth and death rates, poverty ratios, illiteracy and maternal mortality, and infant mortality rates. These states also have very low rates of school enrolment and their per capita net state domestic product is among the lowest in the country. As high as 42.6 percent of Bihar's population and 31.1 percent of Uttar Pradesh's population was below the poverty line in 1999/00. Among the other major states, Orissa and Madhya Pradesh have very high poverty ratios.

The 2001 census highlighted the grave demographic situation of Uttar Pradesh. Sixteen percent of India's population lives in Uttar Pradesh, although the state accounts for only 7.5 percent of the country's total area. In March 2001, the state's population

\footnotetext{
${ }^{22}$ For China, refer to Demurger et al. (2002)

${ }^{23}$ Of the ten Prime Ministers' that India has had since independence, six of them have come from Uttar Pradesh and in addition, of the 425 Members of Parliament in the Lok Sabha (lower house), 85 of them come from Uttar Pradesh. Bihar accounts for 58 Members of Parliament, second highest after Uttar Pradesh.
} 
was a placed at 166 million $\frac{24}{4}$, with a very high population density - 689 persons per square kilometer. The state's population density is more than twice the national average, which is 324. Uttar Pradesh's population has increased almost three times since independence. It is increasing at the rate of 2.3 percent per year, up from 2.28 percent during 1981-91. That is, Uttar Pradesh is now adding about 3.8 million people per year. If the population growth rate in the state is not checked, in 30 years, Uttar Pradesh's population would have reached 340 million, which was the population of the entire country after partition in 1947.

On the political front, while there seems to be some degree of consensus on the basic direction of reforms, however, there have been several instances when the political parties have supported reforms when in power, and opposed them, when in opposition. Since 1991, every ruling party has supported reforms while the same party when in the opposition has tried to block them. For instance, the BJP opposed the opening-up of the insurance industry when the Congress wanted to do so, and later the Congress opposed the same reform when the ruling BJP wanted to open-up the insurance industry. Of course, the Congress agreed eventually and the insurance reforms went through ${ }^{25}$. Similarly, the BJP had a tough time privatizing a state-owned Aluminum firm Balco as the Congress opposed this move. Once again, even though the firm did get privatized, it was not until a Supreme Court judgment came through. An important aspect of the unfinished agenda should therefore be wide dissemination of information and debate about the necessity of reforms, which should include a frank discussion on some its temporary negative consequences and ways of ameliorating their impact.

In conclusion, a decade of opening of the economy has produced new dynamism, most dramatically in the information technology sector, but in others as well. The new technologies (especially information technology and biotechnology) give new opportunities for economic and social development. The reforms implemented so far have helped India attain 6 plus percent growth, however, should India be able to implement these remaining reforms and re-orient governmental spending away from inessential expenditures towards high priority areas of health and education and infrastructure development, then it is very likely to attain and sustain even higher rates of economic growth. If India does grow consistently at around 7/8 percent per year, this is likely to push up its domestic savings in the next few years. Besides, stronger growth should attract more foreign savings, especially foreign direct investment, and thus raise the investment rate.

\footnotetext{
${ }^{24}$ If Uttar Pradesh were to be a separate country, it would be the sixth most populous country in the world after China, India, United States, Indonesia and Brazil.

${ }^{25}$ This could not have been possible but for the untiring efforts of Dr. Manmohan Singh who convinced his party, the Congress, to support the legislation for opening-up the insurance industry in the Upper House of the Parliament (Rajya Sabha), where the Congress has a majority.
} 


\section{REFERENCES}

Ahluwalia, Isher and I. M. D. Little, (1998). “India's Economic Reforms and Development Essays for Manmohan Singh”, Oxford University Press, New Delhi.

Bajpai, Nirupam, (2001). "Sustaining High Rates of Economic Growth in India", CID Working Paper No. 65, Center for International Development, Harvard University.

Bajpai, Nirupam and Jeffrey D. Sachs, (2000). “India's Decade of Development”, CID Working Paper No. 46, Center for International Development, Harvard University.

Bajpai, Nirupam and Jeffrey D Sachs, (1997a). "Fiscal Policy in India's Economic Reforms", Harvard Institute for International Development, Development Discussion Paper No. 577, Conference Paper Series, Harvard University.

Bajpai, Nirupam and Jeffrey D Sachs, (1997b). "India's Economic Reforms: Some Lessons from East Asia”, Journal of International Trade and Economic Development, 6:2.

Chelliah, Raja, (1996). "Towards Sustainable Growth: Essays in Fiscal and Financial Sector Reforms in India”, Oxford University Press, New Delhi.

CMIE, Economic Intelligence Service, (2002). Public Finance.

Demurger, S, Jeffrey D Sachs, Wing Thye Woo, Shuming Bao, Gene Chang, and Andrew Mellinger. (2001) "Geography, Economic Policy and Regional Development in China", CID Working Paper No. 77, Center for International Development, Harvard University, forthcoming Asian Economic Papers, MIT Press, Vol. 1, No. 1.

Global Competitiveness Report, 2001/02, (2002). World Economic Forum and the Center for International Development, Harvard University, Oxford University Press.

Government of India, Ministry of Finance, (2002). Finance Minister's Budget Speech, New Delhi.

Government of India, (2001). Census of India - Provisional Population Totals, Series 1, New Delhi.

Government of India, Economic Survey, Ministry of Finance, various issues.

Government of India, Planning Commission, (2000). "Mid Term Appraisal of Ninth Five Year Plan (1997-2002)", New Delhi.

Government of India, National Accounts Statistics, Central Statistical Organization, various issues.

Government of India, Department of Economic Affairs, Ministry of Finance, (1993).

"Economic Reforms - Two Years After and the Tasks Ahead", Discussion Paper, New Delhi.

India Infrastructure Report, (1996). Volumes I, II, and III - Policy Imperatives for Growth and Welfare, New Delhi. 
Jalan, Bimal, (1996). "India's Economic Policy: Preparing for the Twenty-First Century", Viking Penguin India, New Delhi.

Joshi, Vijay and I.M.D. Little, (1996). “India's Economic Reforms - 1991-2001”, Oxford University Press, New Delhi.

Reserve Bank of India, Report on Currency and Finance, various issues.

Sachs, Jeffrey, Nirupam Bajpai, and Ananthi Ramiah (2002). "Understanding Regional Economic Growth in India”, CID Working Paper No. 88, Center for International Development, Harvard University. Also, forthcoming in Asian Economic Papers, MIT Press, Vol. 1, No. 2.

Sachs, Jeffrey and Nirupam Bajpai, (2000). "The Decade of Development: Goal Setting and Policy Challenges in India”, CID Working Paper No. 62, Center for International Development, Harvard University.

Sachs, Jeffrey, Ashutosh Varshney, and Nirupam Bajpai, (1999). "India in the Era of Economic Reforms" Oxford University Press, New Delhi.

Shome, Parthasarathi, (1997). "Value Added Tax in India - A Progress Report", National Institute of Public Finance and Policy, New Delhi.

Srivastava, D.K., and Tapas K Sen, (1997). "Government Subsidies in India", National Institute of Public Finance and Policy, New Delhi. 
Table 1: Trends of Major Macroeconomic Indicators: 1990-91 --- 2001-02

\begin{tabular}{|c|c|c|c|c|c|c|}
\hline ITEMS & $1990-91$ & $1991-92$ & 1998-99 & $1999-2000$ & $2000-01$ & $2001-02$ \\
\hline $\begin{array}{l}\text { 1. Growth rates (per cent): } \\
\text { GDP at constant factor cost } \\
\text { Industrial production (IIP) } \\
\text { of which, Electricity } \\
\text { Agricultural production (crop index based) } \\
\text { Food grain production } \\
\text { Exports (BOP in terms of US \$) } \\
\text { Imports (BOP in terms of US \$) } \\
\text { of which POL }\end{array}$ & $\begin{array}{l}5.6 \\
8.2 \\
7.8 \\
3.8 \\
3.1 \\
9.0 \\
14.4 \\
60.0\end{array}$ & $\begin{array}{l}1.3 \\
0.6 \\
8.5 \\
-2.0 \\
-4.5 \\
-1.1 \\
-24.5 \\
-11.7\end{array}$ & $\begin{array}{l}6.5 \\
4.1 \\
6.5 \\
7.6 \\
5.9 \\
-3.9 \\
-7.1 \\
-21.6\end{array}$ & $\begin{array}{l}6.1 \mathrm{P} \\
6.7 \\
7.3 \\
-0.9 \\
3.0 \\
9.5 \\
16.5 \\
97.1\end{array}$ & $\begin{array}{l}4.0 \mathrm{Q} \\
5.0 \\
4.0 \\
-6.6 \mathrm{P} \\
-6.6 \mathrm{P} \\
19.6 \\
7.0 \\
24.1\end{array}$ & $\begin{array}{l}5.4 \mathrm{~A} \\
2.3 \mathrm{c} \\
2.7 \mathrm{c} \\
6.9 \mathrm{P} \\
6.8 \mathrm{P} \\
0.6 \mathrm{~b} \\
0.3 \mathrm{~b} \\
-14.6 \mathrm{~b}\end{array}$ \\
\hline 2. Food grains prod. (million tones) & 176.4 & 168.4 & 203.6 & 209.8 & 195.9 P & $209.2 \mathrm{P}$ \\
\hline 3. Electricity generated (million Kwh) & 264.3 & 287.0 & 448.5 & 480.7 & 499.6 & $383.2 \mathrm{c}$ \\
\hline 4. Average exchange rate( Rs. /US\$) & 17.94 & 24.65 & 42.07 & 4.33 & 45.68 & $47.49 \mathrm{~d}$ \\
\hline 5. Growth rate of money supply (M3) & 15.1 & 19.3 & 19.4 & 14.6 & 16.7 & $11.2 \mathrm{e}$ \\
\hline $\begin{array}{l}\text { 6. Average rate of inflation (per cent) } \\
\text { In terms of WPI } \\
\text { In terms of CPI }\end{array}$ & $\begin{array}{l}12.1 \\
13.6 \\
\end{array}$ & $\begin{array}{l}13.6 \\
13.9 \\
\end{array}$ & $\begin{array}{l}5.9 \\
13.1 \\
\end{array}$ & $\begin{array}{l}3.3 \\
3.4 \\
\end{array}$ & $\begin{array}{l}7.1 \\
3.7 \\
\end{array}$ & $\begin{array}{l}4.4 \mathrm{f} \\
4.2 \mathrm{~g} \\
\end{array}$ \\
\hline $\begin{array}{l}\text { 7. As per cent of GDP at current market prices: } \\
\text { Gross domestic savings } \\
\text { Gross domestic investment } \\
\text { Central Government expenditure } \\
\text { Central Government receipts } \\
\text { Gross fiscal deficit of Central Govt. } \\
\text { Exports fob (BOP) } \\
\text { Imports cif (BOP) } \\
\text { Trade balance } \\
\text { Net invisibles } \\
\text { Current account balance } \\
\text { Total capital flows } \\
\text { Total foreign investment net (BOP) } \\
\text { Foreign direct investment (FDI) net } \\
\text { Portfolio investment }\end{array}$ & $\begin{array}{l}23.1 \\
26.3 \\
17.3 \\
15.3 \\
6.6 \\
\\
5.8 \\
8.8 \\
-3.0 \\
-0.1 \\
-3.1 \\
\\
2.7 \\
0.03 \\
0.03 \\
\text { Negl. }\end{array}$ & $\begin{array}{l}22.0 \\
22.6 \\
16.2 \\
15.2 \\
4.7 \\
\\
6.9 \\
7.9 \\
-1.0 \\
0.7 \\
-0.3 \\
\\
1.7 \\
0.05 \\
0.05 \\
\text { Negl. }\end{array}$ & $\begin{array}{l}21.7 \\
22.7 \\
14.7 \\
14.7 \\
5.1 \\
\\
8.3 \\
11.5 \\
-3.2 \\
2.2 \\
-1.0 \\
\\
1.9 \\
0.6 \\
0.6 \\
0.02\end{array}$ & $\begin{array}{l}23.2 \\
24.3 \\
15.4 \\
15.4 \\
5.4 \\
\\
8.4 \\
12.4 \\
-4.0 \\
3.0 \\
-1.1 \\
\\
2.4 \\
1.2 \\
0.5 \\
0.7\end{array}$ & $\begin{array}{l}23.4 \\
24.0 \\
15.3 \mathrm{PU} \\
15.3 \mathrm{PU} \\
5.5 \mathrm{PU} \\
\\
9.8 \\
13.0 \\
-3.1 \\
2.6 \\
-0.5 \\
\\
1.8 \\
1.0 \\
0.4 \\
0.6\end{array}$ & $\begin{array}{l}16.4 \mathrm{BE} \dagger \\
16.4 \mathrm{BE} \dagger \\
5.1 \mathrm{BE} \dagger\end{array}$ \\
\hline $\begin{array}{l}\text { 8. Parameters for external debt: } \\
\text { External debt/GDP ratio (percent) } \\
\text { Debt service ratio (percent) } \\
\text { Debt/ exports ratio } \\
\text { Short-term debt to total debt ratio (\%) }\end{array}$ & $\begin{array}{l}28.7 \\
35.3 \\
454 \\
10.2 \\
\end{array}$ & $\begin{array}{l}38.7 \\
30.2 \\
467 \\
8.3 \\
\end{array}$ & $\begin{array}{l}23.6 \\
18.0 \\
283 \\
4.4 \\
\end{array}$ & $\begin{array}{l}22.2 \\
16.2 \\
262 \\
4.0 \\
\end{array}$ & $\begin{array}{l}22.3 \\
17.1 \\
222 \\
3.5 \\
\end{array}$ & $\begin{array}{l}21.0 \mathrm{~h} \\
2.8 \mathrm{~h}\end{array}$ \\
\hline $\begin{array}{l}\text { 9. Foreign exch. reserves (US\$ bn) } \\
\text { Import cover of foreign exch. } \\
\text { reserves (in no. of months of imports) }\end{array}$ & $\begin{array}{l}\mathbf{5 . 8} \\
2.5\end{array}$ & $\begin{array}{l}9.2 \\
5.3\end{array}$ & \begin{tabular}{|l|}
$\mathbf{3 2 . 5}$ \\
8.2
\end{tabular} & $\begin{array}{l}\mathbf{3 8 . 0} \\
8.2\end{array}$ & $\begin{array}{l}42.3 \\
8.6\end{array}$ & $\begin{array}{l}49.5 * \\
9.6\end{array}$ \\
\hline \multicolumn{7}{|c|}{ 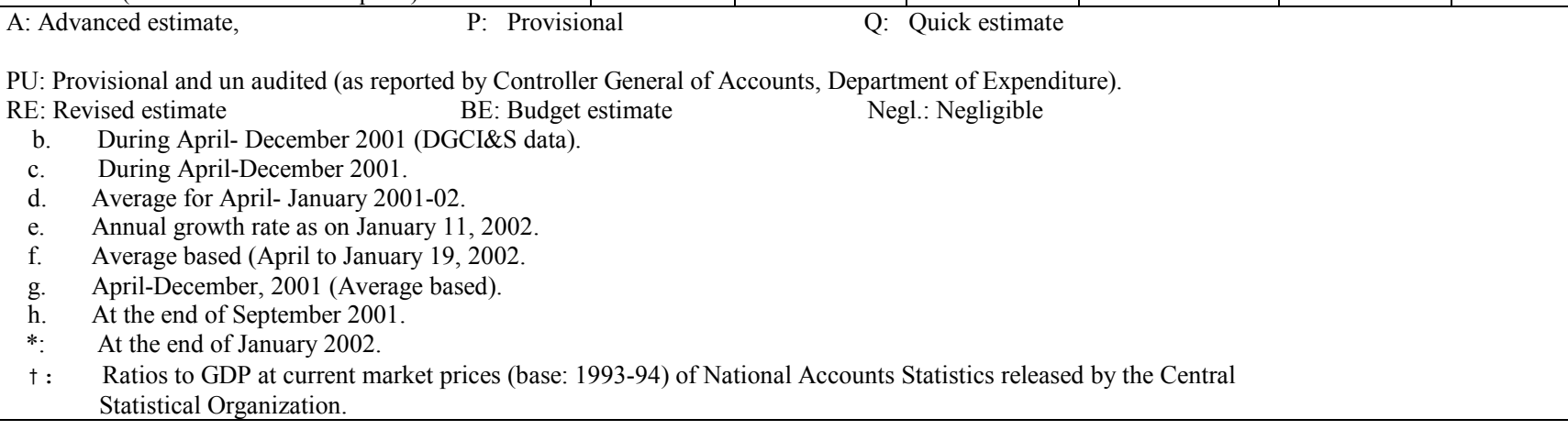 } \\
\hline
\end{tabular}

Source: Economic Survey, Ministry of Finance, Government of India, various issues. 
Table 2: Key Indicators $(1991 / 92-1994 / 95)$

\begin{tabular}{|c|c|c|c|c|c|c|c|c|}
\hline \multirow[b]{3}{*}{1} & $\begin{array}{l}1991- \\
1992\end{array}$ & $\begin{array}{l}1992- \\
1993 P\end{array}$ & $\begin{array}{l}1993- \\
1994 \mathrm{P}\end{array}$ & $\begin{array}{l}1994- \\
1995 \mathrm{P}\end{array}$ & $\begin{array}{l}1991- \\
1992\end{array}$ & $\begin{array}{l}1992- \\
1993 P\end{array}$ & $\begin{array}{l}1993- \\
1994 \mathrm{P}\end{array}$ & $\begin{array}{l}1994- \\
1995 \mathrm{P}\end{array}$ \\
\hline & & \multicolumn{2}{|c|}{ Absolute Values } & \multicolumn{5}{|c|}{ Per Cent Change Over Previous Year } \\
\hline & 2 & 3 & 4 & 5 & 6 & 7 & 8 & 9 \\
\hline $\begin{array}{l}\text { Gross national } \\
\text { product ( Rs. } \\
\text { thousand crore) } \\
\text { At current prices } \\
\text { At } 1980-81 \text { prices } \\
\end{array}$ & $\begin{array}{l}542.0 \\
209.8\end{array}$ & $\begin{array}{l}615.8 \\
218.7 \\
\end{array}$ & $\begin{array}{l}695.3 \mathrm{Q} \\
228.7 \mathrm{Q} \\
\end{array}$ & $240.9 \mathrm{E}$ & $\begin{array}{l}15.2 \\
0.6\end{array}$ & $\begin{array}{l}13.6 \\
4.2\end{array}$ & $\begin{array}{l}12.9 \mathrm{Q} \\
4.6 \mathrm{Q}\end{array}$ & $5.4 \mathrm{E}$ \\
\hline $\begin{array}{l}\text { Gross domestic } \\
\text { product (Rs. } \\
\text { thousand crore) } \\
\text { At current prices } \\
\text { At } 1980-81 \text { prices }\end{array}$ & $\begin{array}{l}552.0 \\
214.2\end{array}$ & $\begin{array}{c}627.6 \\
223.4\end{array}$ & $\begin{array}{l}707.1 Q \\
233.0 Q\end{array}$ & $245.3 \mathrm{E}$ & $\begin{array}{l}15.5 \\
0.9\end{array}$ & $\begin{array}{c}13.7 \\
4.3\end{array}$ & $\begin{array}{l}12.7 \mathrm{Q} \\
4.3 \mathrm{Q}\end{array}$ & $5.3 \mathrm{E}$ \\
\hline $\begin{array}{l}\text { Agricultural } \\
\text { production (1) }\end{array}$ & 145.5 & 151.5 & 154.8 & $158.2 \mathrm{~A}$ & -2.0 & 4.1 & 2.2 & $2.2 \mathrm{~A}$ \\
\hline $\begin{array}{l}\text { Food grain } \\
\text { production } \\
\text { (million tonnes) }\end{array}$ & 168.4 & 179.5 & 182.1 & 185.0 & -4.5 & 6.6 & 1.4 & $1.6 \mathrm{~A}$ \\
\hline $\begin{array}{l}\text { Industrial } \\
\text { production (2) }\end{array}$ & 213.9 & 218.9 & 227.8 & $232.8(3)$ & 0.6 & 2.3 & 4.1 & $8.0(3)$ \\
\hline $\begin{array}{l}\text { Electricity } \\
\text { generated (Billion } \\
\mathrm{KWH} \text { ) }\end{array}$ & 287.0 & 301.1 & 323.5 & $257.9(8)$ & 8.6 & 4.9 & 7.5 & $8.4(8)$ \\
\hline $\begin{array}{l}\text { Wholesale price } \\
\text { index (4) }\end{array}$ & 217.8 & 233.1 & 258.3 & $284.3(5)$ & 13.6 & 7.0 & 10.8 & $11.5(5)$ \\
\hline $\begin{array}{l}\text { Consumer price } \\
\text { index for } \\
\text { industrial workers } \\
\text { (6) }\end{array}$ & 229.0 & 243.0 & 267.0 & $289.0(7)$ & 13.9 & 6.1 & 9.9 & $9.5(7)$ \\
\hline $\begin{array}{l}\text { Money supply } \\
\text { (M3) (12) } \\
\text { (Rs. thousand } \\
\text { crore) }\end{array}$ & 317.0 & 366.8 & 433.6 & $498.4(10)$ & 19.4 & 15.7 & 18.2 & $18.6(11)$ \\
\hline $\begin{array}{l}\text { Imports at current } \\
\text { prices (US \$ } \\
\text { million) }\end{array}$ & 19411 & 21882 & 23213 & $22708(8)$ & -19.4 & 12.7 & 6.1 & $23.6(8)$ \\
\hline $\begin{array}{l}\text { Exports at current } \\
\text { prices (US \$ } \\
\text { million) }\end{array}$ & 17865 & 18537 & 22174 & 20871(8) & -1.5 & 3.8 & 19.6 & $17.3(8)$ \\
\hline $\begin{array}{l}\text { Foreign currency } \\
\text { assets (US \$ } \\
\text { million) }\end{array}$ & 5631 & 6434 & 15068 & 19651(9) & 151.8 & 14.3 & 134.2 & $30.4(9)$ \\
\hline $\begin{array}{l}\text { Exchange rate } \\
(\text { Rs/US \$ })^{a, b}\end{array}$ & 24.65 & 28.96 & 31.37 & $31.38(8)$ & 27.2 & 14.9 & 7.7 & $0.1(8)$ \\
\hline $\begin{array}{cc}\text { Note: Gross nation } \\
\text { A- } & \text { Anticip } \\
\text { a } & \text { Per cen } \\
\text { b } & \text { Compo } \\
\text { 1. } & \text { Index o } \\
& 1981-8 \\
\text { 2. } & \text { Index o } \\
\text { 3. } & \text { Averag } \\
4 . & \text { Index w } \\
& \text { the inde } \\
\text { 5. } & \text { As on F } \\
& \text { years. } \\
\text { 6. } & \text { Index w } \\
& \text { index o } \\
\text { 7. } & \text { As in D } \\
\text { 8. } & \text { April-Ja } \\
\text { 9. } & \text { As on F } \\
\text { 10. } & \text { As on J } \\
\text { 11. } & \text { April 1, } \\
\text { 12. } & \text { Percent }\end{array}$ & $\begin{array}{l}1 \text { product } \\
\text { ted; P-Pr } \\
\text { change } \\
\text { ite rate fr } \\
\text { agricultu } \\
=100 \\
\text { industria } \\
\text { index fo } \\
\text { th base 1 } \\
\text { over the } \\
\text { bruary } 1 \\
\text { th base 1 } \\
\text { er the ye } \\
\text { cember, } \\
\text { nuary, } 19 \\
\text { bruary } 1 \\
\text { nuary } 20 \\
\text { 1994-Jan } \\
\text { ges relate }\end{array}$ & $\begin{array}{l}\text { Gross do } \\
\text { onal, Q- } \\
\text { ates the rc } \\
\text { March 19s } \\
\text { roduction } \\
\text { duction } 1 \\
\text { il-Octobe } \\
82=100 \text {. I } \\
\\
5 \text { for } 199 \\
100 \text {. Perc } \\
\text { and in M } \\
5 . \\
95 \text { for } 19 \\
5 . \\
20,1995 \\
\text { oint-to-pc }\end{array}$ & $\begin{array}{l}\text { product } f \\
\text { stimates; } \\
\text { epreciati } \\
\text { ebruary } 1 \\
\text { ipal crops } \\
=100 \\
\text { age relate } \\
\text { nd for the } \\
\text { relate to } \\
\text { or the earl } \\
\text { and the en } \\
\text { anges ove }\end{array}$ & $\begin{array}{l}\text { are at facto } \\
\text { vance estim } \\
\text { he Rupee. } \\
\text { base trienn } \\
\text { int-to-point } \\
\text { yeek of Mar } \\
\text { to-point ch } \\
\text { ars. } \\
\text { Uarch for th } \\
\text { ear. }\end{array}$ & $\begin{array}{l}\text { nding } \\
\text { ges in } \\
\text { the earlier } \\
\text { in the } \\
\text { jious years }\end{array}$ & 10 milli & & \\
\hline
\end{tabular}


Table 2 contd: Key Indicators (1998/99 - 2001/02)

\begin{tabular}{|c|c|c|c|c|c|c|c|c|}
\hline & $\begin{array}{l}1998- \\
1999\end{array}$ & $\begin{array}{l}1999- \\
2000\end{array}$ & $\begin{array}{l}2000- \\
2001\end{array}$ & $\begin{array}{l}2001- \\
2002\end{array}$ & $\begin{array}{l}1998- \\
1999\end{array}$ & $\begin{array}{l}1999- \\
2000\end{array}$ & $\begin{array}{l}2000- \\
2001\end{array}$ & $\begin{array}{l}2001- \\
2002\end{array}$ \\
\hline & & \multicolumn{2}{|c|}{ Absolute Values } & \multicolumn{5}{|c|}{ Per Cent Change Over Previous Year } \\
\hline $\begin{array}{l}\text { Gross national product } \\
\text { (Rs. thousand crore) } \\
\text { At current prices } \\
\text { At } 1993-94 \text { prices }\end{array}$ & $\begin{array}{l}1,583.1 \\
1,070.5\end{array}$ & $\begin{array}{l}1,740.2 \mathrm{P} \\
1,136.9 \mathrm{P}\end{array}$ & $\begin{array}{l}1,878.4 \mathrm{Q} \\
1,181.5 \mathrm{Q}\end{array}$ & $\begin{array}{l}2,060.6 \mathrm{~A} \\
1,245.5 \mathrm{~A}\end{array}$ & $\begin{array}{l}15.0 \\
6.4\end{array}$ & $\begin{array}{l}9.9 \mathrm{P} \\
6.2 \mathrm{P}\end{array}$ & $\begin{array}{l}7.9 \mathrm{Q} \\
3.9 \mathrm{Q}\end{array}$ & $\begin{array}{l}9.7 \mathrm{~A} \\
5.4 \mathrm{~A}\end{array}$ \\
\hline $\begin{array}{l}\text { Gross domestic product } \\
\text { (Rs. thousand crore) } \\
\text { At current prices } \\
\text { At } 1993-94 \text { prices }\end{array}$ & $\begin{array}{l}1,598.1 \\
1,082.5\end{array}$ & $\begin{array}{l}1,755.6 \mathrm{P} \\
1,148.5 \mathrm{P}\end{array}$ & $\begin{array}{l}1,895.8 \mathrm{Q} \\
1,193.9 \mathrm{Q}\end{array}$ & $\begin{array}{l}2,080.3 \mathrm{~A} \\
1,258.8 \mathrm{~A}\end{array}$ & $\begin{array}{l}15.0 \\
6.5\end{array}$ & $\begin{array}{l}9.9 \mathrm{P} \\
6.1 \mathrm{P}\end{array}$ & $\begin{array}{l}8.0 \mathrm{Q} \\
4.0 \mathrm{Q}\end{array}$ & $\begin{array}{l}9.7 \mathrm{~A} \\
5.4 \mathrm{~A}\end{array}$ \\
\hline $\begin{array}{l}\text { Agriculture and allied } \\
\text { sectors (Rs. crore) } \\
\text { (at 1993-94 prices) }\end{array}$ & $2,86,094$ & $2,89,842$ & $2,89,194$ & $3,05,643$ & 6.2 & 1.3 & -0.2 & 5.7 \\
\hline $\begin{array}{l}\text { Index of agricultural } \\
\text { production (1) }\end{array}$ & 177.9 & $176.2 \mathrm{P}$ & $164.6 \mathrm{P}$ & $175.9 \mathrm{P}$ & 7.6 & $-0.9 \mathrm{P}$ & $-6.6 \mathrm{P}$ & $6.9 \mathrm{P}$ \\
\hline $\begin{array}{l}\text { Food grain production } \\
\text { (million tonnes) }\end{array}$ & 203.6 & 209.8 & $195.9 \mathrm{P}$ & 209.2 P & 5.9 & 3.0 & $-6.6 \mathrm{P}$ & $6.8 \mathrm{P}$ \\
\hline $\begin{array}{l}\text { Index of industrial } \\
\text { production }(2)\end{array}$ & 145.2 & 154.9 & 162.7 & $163.3 * *$ & 4.1 & 6.7 & 5.0 & $2.3 * *$ \\
\hline $\begin{array}{l}\text { Electricity generated } \\
\text { (Billion Kwh) }\end{array}$ & 448.5 & 480.7 & 499.6 & $383 . .2 * *$ & 6.6 & 7.2 & 3.9 & $2.8 * *$ \\
\hline Wholesale price index (3) & 141.7 & 150.9 & 159.2 & $160.7 *$ & 5.3 & 6.5 & 4.9 & $1.3 *$ \\
\hline $\begin{array}{l}\text { Consumer price index for } \\
\text { industrial workers (4) }\end{array}$ & 414 & 434 & 445 & $469 @$ & 8.9 & 4.8 & 2.5 & $5.2 @$ \\
\hline $\begin{array}{l}\text { Money supply (M3) (5) } \\
\text { (Rs. thousand crore) }\end{array}$ & 981.0 & $1,124.2$ & $1,311.6$ & $1,458.4(6)$ & 19.4 & 14.6 & 16.7 & $11.2(6)$ \\
\hline $\begin{array}{l}\text { Imports at current prices } \\
\text { (US \$ million) }\end{array}$ & 42,389 & 49,671 & 50,536 & $38,362 * *$ & 2.2 & 17.2 & 1.7 & $0.3 * *$ \\
\hline $\begin{array}{l}\text { Exports at current prices } \\
\text { (US \$ million) }\end{array}$ & 33,218 & 36,822 & 44,560 & $32,572 * *$ & -5.1 & 10.8 & 21.0 & $0.6 * *$ \\
\hline $\begin{array}{l}\text { Foreign currency assets } \\
\text { (7) (US \$ million) }\end{array}$ & 29,522 & 35,058 & 39,554 & $46,561(8)$ & 13.7 & 18.8 & 12.8 & $17.7(8)$ \\
\hline $\begin{array}{l}\text { Exchange rate (Rs/US \$) } \\
\text { (9) }\end{array}$ & 42.07 & 43.33 & 45.68 & $47.49(10)$ & -11.7 & -2.9 & -5.1 & $-3.8(10)$ \\
\hline $\begin{array}{cc}\text { Note: Gross national produ } \\
\text { Q- Quick estimates; } \\
\text { *: As on 19.01.2002 } \\
\text { 1. } & \text { Index of agricul } \\
& 1981-82=100 \\
\text { 2. } & \text { Index of industr } \\
\text { 3. } & \text { Index (with bas } \\
\text { 4. } & \text { Index (with bas } \\
\text { 5. } & \text { Outstanding at } \\
\text { 6. } & \text { As on January } 1 \\
\text { 7. } & \text { Outstanding at } \\
\text { 8. } & \text { At the end of Ja } \\
\text { 9. } & \text { Percent change } \\
\text { 10. } & \text { Average for Ap }\end{array}$ & $\begin{array}{l}t \text { and Gross } \\
\text { (provisional } \\
\text { ural product } \\
\text { evised). } \\
\text { al productio } \\
1993-94=1 \\
1982=100 \text { ) } \\
\text { e end of fis } \\
\text { 2002. } \\
\text { e end of fis } \\
\text { uary, 2002. } \\
\text { ndicates the } \\
1 \text { - January, }\end{array}$ & $\begin{array}{l}\text { estic product } \\
\text { Advance; } \\
\quad \text { @ : De } \\
\text { of } 46 \text { crops, } \\
\text { ase 1993-94 } \\
\text { the end of } \\
\text { ne end of fisc } \\
\text { ear. } \\
\text { ear. } \\
\text { of appreciati } \\
1-2002 \text {. }\end{array}$ & $\begin{array}{l}\text { res are at fac } \\
\text { ding plantat } \\
\text { ding. } \\
\text { l year. } \\
\text { ar. } \\
\text { epreciation }\end{array}$ & $\begin{array}{l}\text { cost }(\text { New Ser } \\
\text { - Provisional; } \\
* * \text { A April- } \\
\text { with base tri }\end{array}$ & $\begin{array}{l}\text { es; base }= \\
\text { Decembe } \\
\text { ennium e }\end{array}$ & $\begin{array}{l}3-94) . \text { One } \\
01 . \\
\mathrm{g}\end{array}$ & $\mathrm{e}=10 \mathrm{mi}$ & \\
\hline
\end{tabular}

Source: Economic Survey, Ministry of Finance, Government of India, various issues. 
Table 3: Tax Revenue and Expenditures of the Central Government

\begin{tabular}{|c|c|c|c|c|c|c|c|}
\hline & $\begin{array}{l}\text { 1990-91 } \\
\text { Actuals }\end{array}$ & $\begin{array}{l}\text { 1996-97 } \\
\text { Actuals }\end{array}$ & $\begin{array}{l}\text { 1997-98 } \\
\text { Actuals }\end{array}$ & $\begin{array}{l}\text { 1998-99 } \\
\text { Actuals }\end{array}$ & $\begin{array}{l}\text { 1999-2000 } \\
\text { Actuals }\end{array}$ & $\begin{array}{l}2000-01 * \\
\text { (Prov.) }\end{array}$ & $\begin{array}{l}\text { 2001-02\# } \\
(\mathrm{BE})\end{array}$ \\
\hline & & & \multicolumn{5}{|c|}{ (As per cent of GDP) } \\
\hline 1.Fiscal deficit & 6.6 & 4.1 & 4.8 & 5.1 & 5.4 & 5.5 & 5.1 \\
\hline 2..Revenue deficit & 3.3 & 2.4 & 3.1 & 3.8 & 3.5 & 3.9 & 3.4 \\
\hline 3.Primary deficit & 2.8 & -0.2 & 0.5 & 0.7 & 0.7 & 0.8 & 0.2 \\
\hline 4.Gross tax revenue & 10.1 & 9.4 & 9.1 & 8.3 & 8.9 & 9.0 & 9.9 \\
\hline $\begin{array}{l}\text { (a) Direct taxes } \\
\text { of which: }\end{array}$ & 1.9 & 2.8 & 3.2 & 2.7 & 3.0 & 3.3 & 3.7 \\
\hline (i) Income tax & 0.9 & 1.3 & 1.1 & 1.2 & 1.3 & 1.5 & 1.8 \\
\hline (ii) Corporation tax & 0.9 & 1.4 & 1.3 & 1.4 & 1.6 & 1.7 & 1.9 \\
\hline $\begin{array}{l}\text { (b) Indirect taxes } \\
\text { of which: }\end{array}$ & 7.9 & 6.5 & 5.9 & 5.5 & 5.8 & 5.7 & 6.1 \\
\hline (i) Union excise tax & 4.3 & 3.3 & 3.2 & 3.1 & 3.2 & 3.3 & 3.6 \\
\hline (ii) Customs & 3.6 & 3.1 & 2.6 & 2.3 & 2.5 & 2.3 & 2.4 \\
\hline $\begin{array}{l}\text { 5.Total expenditure } \\
\text { of which: }\end{array}$ & 17.3 & 13.9 & 14.2 & 14.7 & 15.4 & 15.3 & 16.4 \\
\hline (i) Interest payments & 3.8 & 4.3 & 4.3 & 4.5 & 4.7 & 4.7 & 4.9 \\
\hline (ii) Major subsides & 1.7 & 1.0 & 1.2 & 1.2 & 1.2 & 1.3 & 1.2 \\
\hline (iii) Defense & 2.7 & 2.2 & 2.3 & 2.3 & 2.4 & 2.4 & 2.7 \\
\hline (iv) Other non-plan expenditure & 4.1 & 2.5 & 2.5 & 2.9 & 3.2 & 3.0 & 3.2 \\
\hline (v) Budget support for plan & 5.0 & 3.9 & 3.9 & 3.8 & 3.9 & 4.0 & 4.4 \\
\hline $\begin{array}{l}* \quad \text { Provisional and un audit } \\
\# \quad \text { The ratios to GDP at curr } \\
\text { Note : } 1 . \text { Ratios to GDP at cu } \\
\\
\text { 2. Statistical Organizat } \\
\text { 2. Figures are exclusiv }\end{array}$ & $\begin{array}{l}\text { reported } \\
\text { narket pr } \\
\text { market } \mathrm{p} \\
\text { he transf }\end{array}$ & $\begin{array}{l}\text { Controller } \\
\text { for 2001-2 } \\
\text { (Base = } \\
\text { State's sl }\end{array}$ & $\begin{array}{l}\text { neral of } \mathrm{A} \\
2 \text { are base } \\
3-94 \text { ) of } \mathrm{N} \\
\text { of net } \mathrm{sm}\end{array}$ & $\begin{array}{l}\text { ints, Depa } \\
\text { CSO' s } \\
\text { nal Accou } \\
\text { avings col }\end{array}$ & $\begin{array}{l}\text { ent of Expen } \\
\text { ance Estimat } \\
\text { Statistics rel } \\
\text { ions. }\end{array}$ & e, Ministry & Finance. \\
\hline
\end{tabular}

Source: Economic Survey, Ministry of Finance, Government of India, various issues. 
Table 4: Sources of Tax Revenue of the Central Government

\begin{tabular}{|c|c|c|c|c|c|c|c|}
\hline & $1990-91$ & $1995-96$ & $1997-98$ & $1998-99$ & $1999-2000$ & $\begin{array}{l}2000-01 \\
(\mathrm{PU})\end{array}$ & $\begin{array}{l}\text { 2001-02 } \\
\mathrm{BE})\end{array}$ \\
\hline \multicolumn{8}{|c|}{ Tax Revenue (Rupees crore) } \\
\hline Direct (a) & 11024 & 33563 & 48274 & 46600 & 57959 & 68194 & 85275 \\
\hline PIT & 5371 & 15592 & 17097 & 20240 & 25647 & 31674 & 40600 \\
\hline CIT & 5335 & 16487 & 20016 & 24529 & 30692 & 35685 & 44200 \\
\hline Indirect (b) & 45158 & 76806 & 89741 & 95871 & 12449 & 118559 & 140142 \\
\hline Customs & 20644 & 35757 & 40193 & 40668 & 48419 & 47623 & 54822 \\
\hline Excise & 24514 & 40187 & 47962 & 53246 & 61902 & 68350 & 81720 \\
\hline Gross Tax Revenue \# & 57576 & 11224 & 139220 & 143797 & 171760 & 188365 & 226649 \\
\hline \multicolumn{8}{|c|}{ Tax Revenue as a percentage of Gross Tax Revenue } \\
\hline Direct (a) & 19.1 & 30.2 & 34.7 & 32.4 & 33.7 & 36.2 & 37.6 \\
\hline PIT & 9.3 & 14.0 & 12.3 & 14.1 & 14.9 & 16.8 & 17.9 \\
\hline CIT & 9.3 & 14.8 & 14.4 & 17.1 & 17.9 & 18.9 & 19.5 \\
\hline Indirect (b) & 78.4 & 69.1 & 64.5 & 66.7 & 65.5 & 62.9 & 61.8 \\
\hline Customs & 35.9 & 32.1 & 28.9 & 28.3 & 28.2 & 25.3 & 24.2 \\
\hline Excise & 42.6 & 36.1 & 34.5 & 37.0 & 36.0 & 36.3 & 36.1 \\
\hline \multicolumn{8}{|c|}{ Tax Revenue as a percentage of Gross Domestic Product* } \\
\hline Direct (a) & 1.9 & 2.8 & 3.2 & 2.7 & 3.0 & 3.3 & 3.7 \\
\hline PIT & 0.9 & 1.3 & 1.1 & 1.2 & 1.3 & 1.5 & 1.8 \\
\hline CIT & 0.9 & 1.4 & 1.3 & 1.4 & 1.6 & 1.7 & 1.9 \\
\hline Indirect (b) & 7.9 & 6.5 & 5.9 & 5.5 & 5.8 & 5.7 & 6.1 \\
\hline Customs & 3.6 & 3.0 & 2.6 & 2.3 & 2.5 & 2.3 & 2.4 \\
\hline Excise & 4.3 & 3.4 & 3.2 & 3.1 & 3.2 & 3.3 & 3.6 \\
\hline Total \# & 10.1 & 9.4 & 9.1 & 8.3 & 8.9 & 9.0 & 9.9 \\
\hline \multicolumn{8}{|l|}{ One crore $=10$ million } \\
\hline \multicolumn{8}{|c|}{$\begin{array}{l}\text { \# Includes taxes referred in (a) \& (b) and taxes of Union Territories and "other" taxes. Tax revenue figures for 2001-2002 are budget } \\
\text { estimates, and for 1999-2000 and earlier years these are actuals. } \\
\text { PU Based on Provisional un audited figures as per Controller General of Accounts. } \\
\text { Refers to gross domestic product at current market prices. The ratios to GDP for 2001-02 are based on CSO's Advance Estimates }\end{array}$} \\
\hline \multicolumn{8}{|c|}{$\begin{array}{l}\text { Note: (a) also includes taxes pertaining to expenditure, interest, wealth, gift, estate duty and VDIS for 1997-98 \& 1998-99; (b) also } \\
\text { includes service tax; }\end{array}$} \\
\hline
\end{tabular}

Source: Economic Survey, Ministry of Finance, Government of India, various issues. 
Table 5: Savings and Investment

\begin{tabular}{|l|l|l|l|l|l|l|l|l|}
\hline & $1994-95$ & $1995-96$ & $1996-97$ & $1997-98$ & $1998-99$ & $\begin{array}{l}1999-2000 \\
(\mathrm{P})\end{array}$ & $\begin{array}{l}2000-01 \\
\text { Q) }\end{array}$ \\
\hline \multicolumn{7}{|c|}{} \\
\hline
\end{tabular}

\section{Real Gross Domestic Capital Formation}

\begin{tabular}{|c|c|c|c|c|c|c|c|}
\hline & $1994-95$ & $1995-96$ & 1996-97 & $1997-98$ & 1998-99 & $\begin{array}{l}1999-2000 \\
(\mathrm{P})\end{array}$ & $\begin{array}{l}2000-01 \\
\text { Q) }\end{array}$ \\
\hline \multicolumn{8}{|c|}{ (As percent of GDP at market prices, $1993-94$ prices) } \\
\hline GDCF* & 26.4 & 27.3 & 25.1 & 25.9 & 24.8 & 26.7 & 26.3 \\
\hline Public & 8.7 & 7.6 & 6.8 & 6.5 & 6.6 & 7.1 & 7.1 \\
\hline Private & 15.0 & 19.3 & 15.5 & 17.3 & 16.7 & 18.5 & 18.0 \\
\hline Pvt. Corporate sector & 7.1 & 9.9 & 8.7 & 9.0 & 7.6 & 7.8 & 7.0 \\
\hline Household sector & 8.0 & 9.4 & 6.9 & 8.3 & 9.1 & 10.6 & 11.0 \\
\hline GFCF & 22.3 & 24.7 & 23.4 & 22.9 & .23 .4 & 23.8 & 23.9 \\
\hline Public & 8.8 & 7.6 & 6.7 & 6.2 & 6.4 & 6.3 & 6.7 \\
\hline Private & 13.5 & 17.1 & 16.7 & 16.6 & 17.0 & 17.5 & 17.2 \\
\hline Change in stocks & 1.4 & 2.2 & -1.0 & 0.9 & -0.1 & 1.8 & 1.1 \\
\hline Public & -0.1 & -0.0 & 0.2 & 0.3 & 0.1 & 0.8 & 0.3 \\
\hline Private & 1.5 & 2.2 & -1.2 & 0.7 & -0.3 & 1.0 & 0.8 \\
\hline \multicolumn{8}{|c|}{ Growth rate in percent } \\
\hline GDCF* & 22.9 & 11.1 & -1.0 & 7.7 & 1.3 & 15.7 & 2.0 \\
\hline Public & 13.9 & -6.5 & -3.1 & -0.8 & 7.3 & 16.2 & 3.0 \\
\hline Private & 24.0 & 38.5 & -13.7 & 16.4 & 2.6 & 18.1 & 1.1 \\
\hline GFCF & 11.8 & 19.3 & 1.5 & 2.1 & 8.7 & 8.6 & 4.7 \\
\hline Public & 18.0 & -6.5 & -5.9 & -2.8 & 9.4 & 4.9 & 10.9 \\
\hline Private & 8.1 & 36.1 & 4.8 & 4.1 & 8.4 & 10.0 & 2.4 \\
\hline \multicolumn{8}{|c|}{$\begin{array}{l}\text { Note: GDCF: Gross domestic capital formation; GDCF: Gross fixed capital formation; } \\
\quad \text { Figures may not add up due to rounding off. } \\
\text { *: Adjusted to errors and omissions; P: Provisional estimates; Q: Quick estimates; } \\
\text { Source: Central Statistical Organization, New Delhi. }\end{array}$} \\
\hline
\end{tabular}


Table 6: Balance of Payments: Summary\#

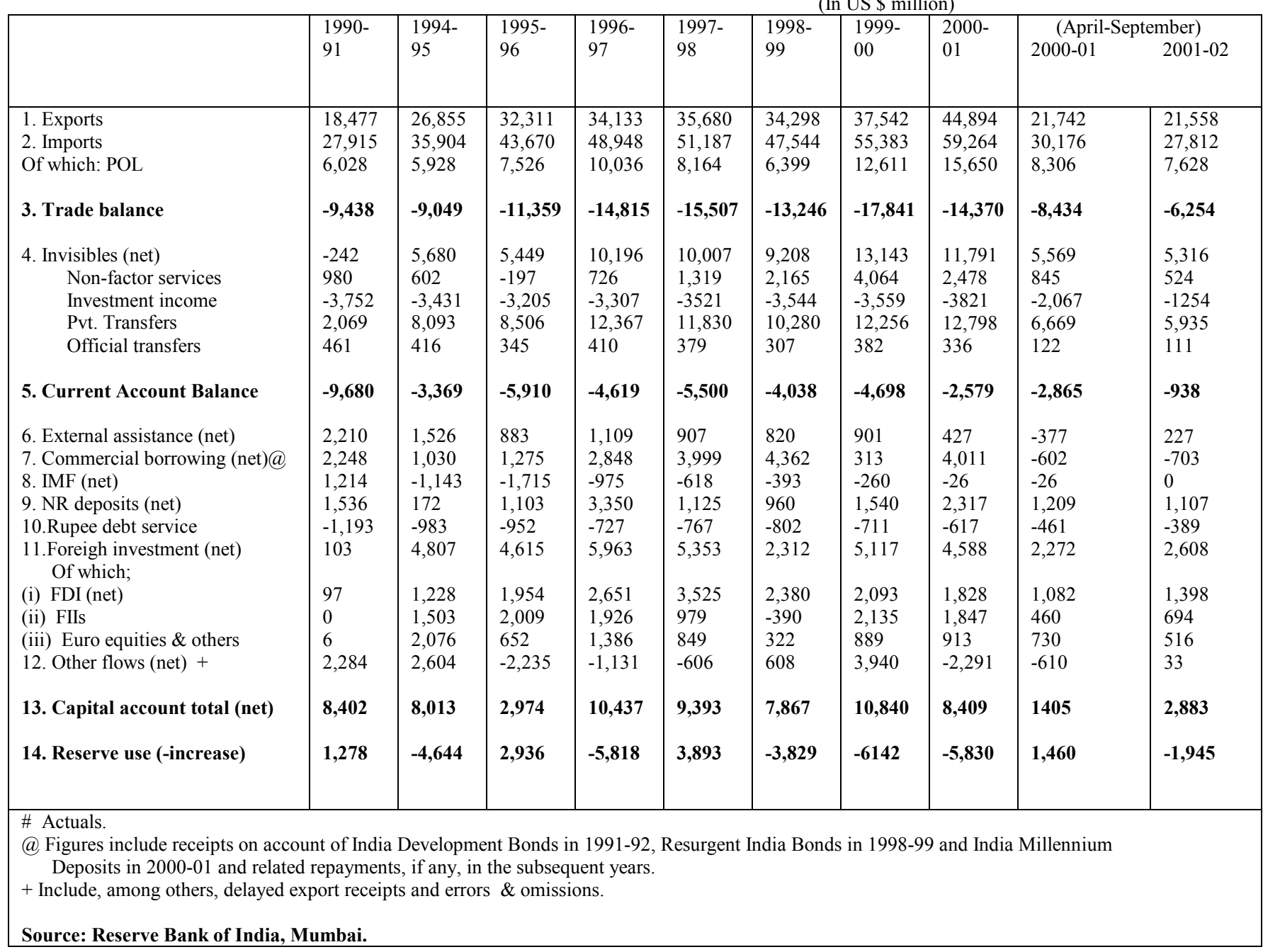


Table 7: Selected Indicators for the External Sector

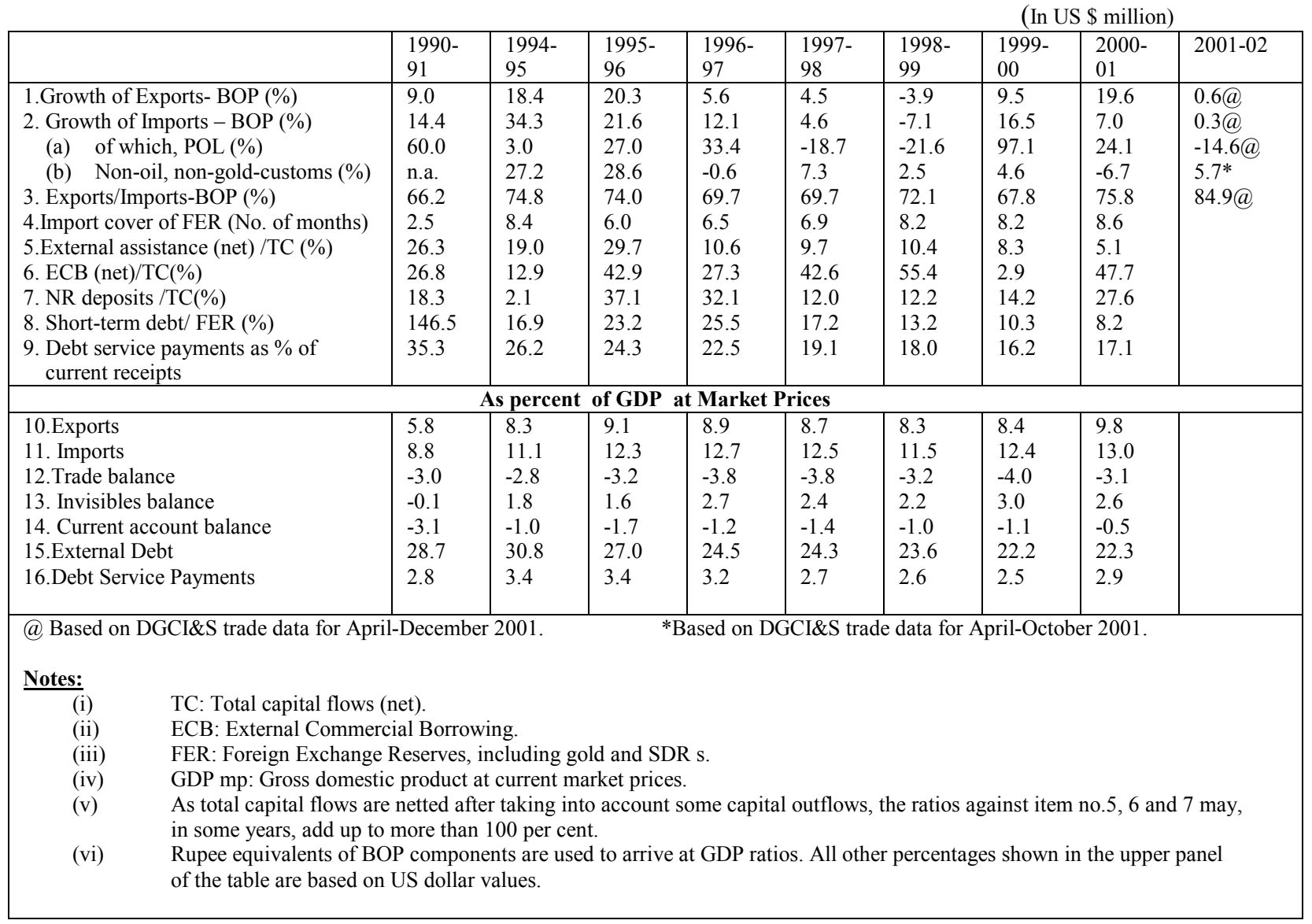

\section{Source: Economic Survey, Ministry of Finance, Government of India, various issues.}


Table 8: Foreign Investment Flows by Different Categories

\begin{tabular}{|c|c|c|c|c|c|c|c|c|c|c|c|c|c|}
\hline & & & & & & & & & & & & \multicolumn{2}{|c|}{ Apr-Nov.* } \\
\hline & $\begin{array}{l}1990 \\
-91\end{array}$ & $\begin{array}{l}1991- \\
92\end{array}$ & $\begin{array}{l}1992- \\
93\end{array}$ & $\begin{array}{l}1993- \\
94\end{array}$ & $\begin{array}{l}1994- \\
95\end{array}$ & $\begin{array}{l}1995- \\
96\end{array}$ & $\begin{array}{l}1990- \\
97\end{array}$ & $\begin{array}{l}1991- \\
98\end{array}$ & $\begin{array}{l}1998- \\
99\end{array}$ & $\begin{array}{l}1999 \\
-00\end{array}$ & $\begin{array}{l}2000- \\
01 *\end{array}$ & $\begin{array}{r}\text { Apr- } \\
2001-01\end{array}$ & $\begin{array}{l}\text { Nov.* } \\
2001-02\end{array}$ \\
\hline A. Direct investment & 97 & 129 & 315 & 586 & 1314 & 2144 & 2821 & 3557 & 2462 & 2155 & 2339 & 1468 & 2365 \\
\hline a. RBI automatic route & - & - & 42 & 89 & 171 & 169 & 135 & 202 & 179 & 171 & 454 & 235 & 538 \\
\hline b. SIA/FIPB route & - & 66 & 222 & 280 & 701 & 1249 & 1922 & 2754 & 1821 & 1410 & 1456 & 915 & 1310 \\
\hline c. NRI s $(40 \% \& 100 \%)$ & - & 63 & 51 & 217 & 442 & 715 & 639 & 241 & 62 & 84 & 67 & 49 & 33 \\
\hline d. Acquisition of shares** & - & - & - & - & - & 11 & 125 & 360 & 400 & 490 & 362 & 269 & 484 \\
\hline B. Portfolio investment & 6 & 4 & 244 & 3567 & 3824 & 2748 & 3312 & 1828 & -61 & 3026 & 2760 & 1037 & 1315 \\
\hline a. F II \# & - & - & 1 & 1665 & 1503 & 2009 & 1926 & 979 & -390 & 2135 & 1847 & 267 & 799 \\
\hline b. G DR s / ADR s@ & - & - & 240 & 1520 & 2082 & 683 & 1366 & 645 & 270 & 768 & 831 & 696 & 477 \\
\hline c. Offshore funds \& others & 6 & 4 & 3 & 382 & 239 & 56 & 20 & 204 & 59 & 123 & 82 & 74 & 39 \\
\hline Total $(\mathrm{A}+\mathrm{B})$ & 103 & 133 & 559 & 4153 & 5138 & 4892 & 6133 & 5385 & 2401 & 5181 & 5099 & 2505 & 3680 \\
\hline $\begin{array}{ll}* & \text { Provisional } \\
* * & \text { Relates to acquisition of } \\
& \text { included as part of FL } \\
\# & \text { Represents fresh inflo } \\
\text { (a) } & \text { Represents the amoun }\end{array}$ & $\begin{array}{l}\text { ares o } \\
\text { since } J \\
\text { of func }\end{array}$ & $\begin{array}{l}\text { ndian c } \\
\text { uary } 19 \\
\text { by For } \\
\text { Indian }\end{array}$ & Institu & 1 Inve & $\begin{array}{l}\text { s under } \\
\text { (FII). } \\
\text { al Depos }\end{array}$ & y Rec & GDR & $\mathrm{d} A \mathrm{~m}$ & Dep & $R$ & te & & \\
\hline
\end{tabular}

Source: Economic Survey, Ministry of Finance, Government of India, various issues. 
Table 9: INDIA - National Competitiveness Balance Sheet

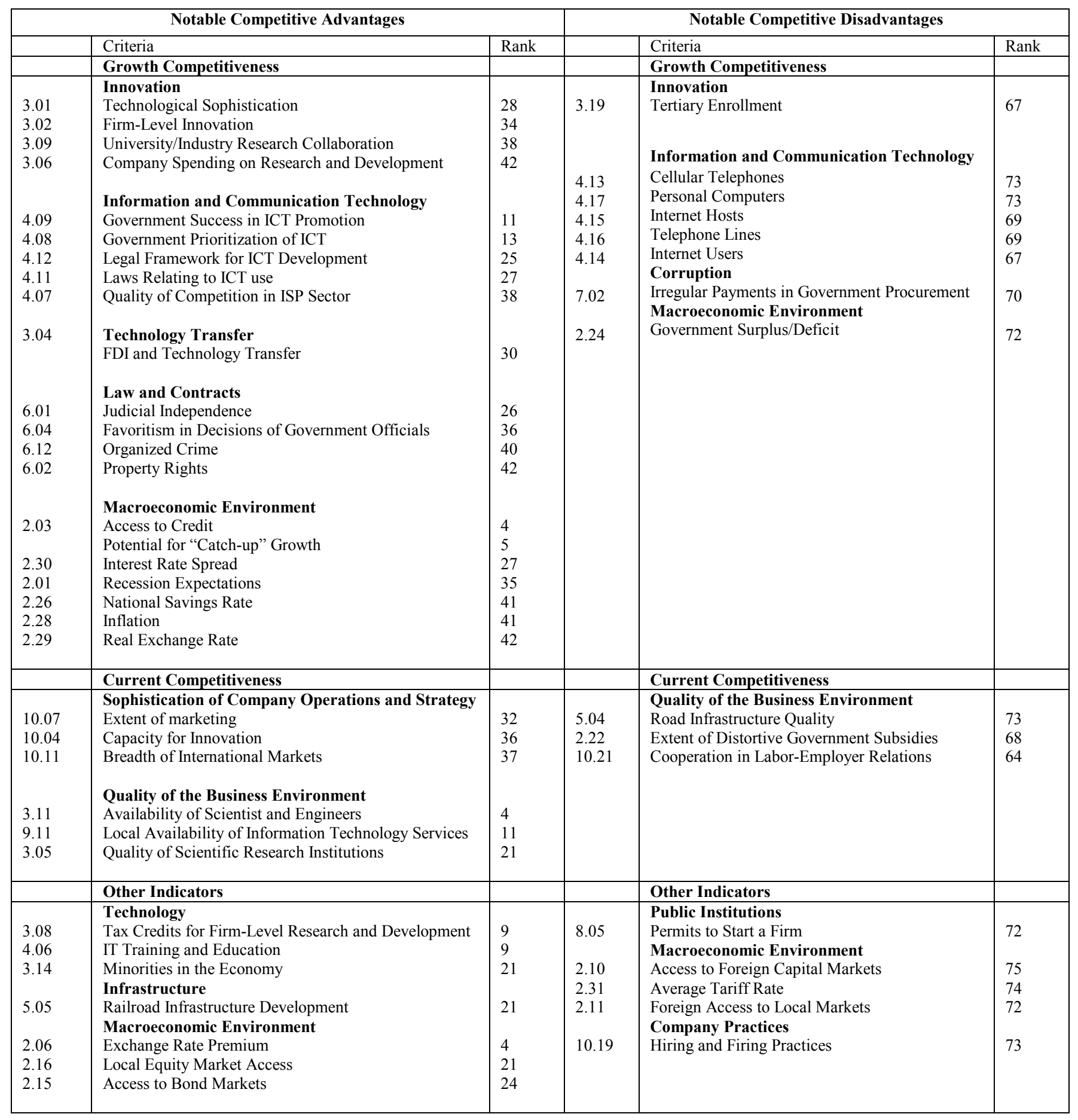

Source: Global Competitiveness Report, 2001/02 
Table 10: Poverty Ratio at the State Level

(Percent)

\begin{tabular}{|c|c|c|c|c|c|c|c|c|c|c|}
\hline \multirow{3}{*}{ S.No. } & \multirow[b]{3}{*}{ State } & \multirow{2}{*}{\multicolumn{3}{|c|}{ Rural }} & \multirow{2}{*}{\multicolumn{3}{|c|}{ Urban }} & \multirow{2}{*}{\multicolumn{3}{|c|}{ Combined }} \\
\hline & & & & & & & & & & \\
\hline & & $\begin{array}{l}1973- \\
74\end{array}$ & $\begin{array}{l}1993- \\
94\end{array}$ & $\begin{array}{l}1999- \\
2000\end{array}$ & $\begin{array}{l}1973- \\
74\end{array}$ & $\begin{array}{l}1993- \\
94\end{array}$ & $\begin{array}{l}1999- \\
2000\end{array}$ & $\begin{array}{l}1973- \\
74\end{array}$ & $\begin{array}{l}1993- \\
94\end{array}$ & $\begin{array}{l}1999 \\
2000\end{array}$ \\
\hline 1. & Andhra Pradesh & 48.41 & 15.92 & 11.05 & 50.61 & 38.33 & 26.63 & 48.86 & 22.19 & 15.77 \\
\hline 2. & Arunachal Pradesh & 52.67 & 45.01 & 40.04 & 36.92 & 7.73 & 7.47 & 51.93 & 39.35 & 33.47 \\
\hline 3. & Assam & 52.67 & 45.01 & 40.04 & 36.92 & 7.73 & 7.47 & 51.21 & 40.86 & 36.09 \\
\hline 4. & Bihar & 62.99 & 58.21 & 44.30 & 52.96 & 34.50 & 32.91 & 61.91 & 54.96 & 42.60 \\
\hline 5. & Goa & 46.85 & 5.34 & 1.35 & 37.69 & 27.03 & 7.52 & 44.26 & 14.92 & 4.40 \\
\hline 6. & Gujarat & 46.35 & 22.18 & 13.17 & 52.57 & 27.89 & 15.59 & 48.15 & 24.21 & 14.07 \\
\hline 7. & Haryana & 34.23 & 28.02 & 8.27 & 40.18 & 16.38 & 9.99 & 35.36 & 25.05 & 8.74 \\
\hline 8. & Himachal Pradesh & 27.42 & 30.34 & 7.94 & 13.17 & 9.18 & 4.63 & 26.39 & 28.44 & 7.63 \\
\hline 9. & Jammu \& Kashmir & 45.51 & 30.34 & 3.97 & 21.32 & 9.18 & 1.98 & 40.83 & 25.17 & 3.48 \\
\hline 10. & Karnataka & 55.14 & 29.88 & 17.38 & 52.53 & 40.14 & 25.25 & 54.47 & 33.16 & 20.04 \\
\hline 11. & Kerala & 59.19 & 25.76 & 9.38 & 62.74 & 24.55 & 20.27 & 59.79 & 25.43 & 12.72 \\
\hline 12. & Madhya Pradesh & 62.66 & 40.64 & 37.06 & 57.65 & 48.38 & 38.44 & 61.78 & 42.52 & 37.43 \\
\hline 13. & Maharashtra & 57.71 & 37.93 & 23.72 & 43.87 & 35.15 & 26.81 & 53.24 & 36.86 & 25.02 \\
\hline 14. & Manipur & 52.67 & 45.01 & 40.04 & 36.92 & 7.73 & 7.47 & 49.96 & 33.78 & 28.54 \\
\hline 15. & Meghalaya & 52.67 & 45.01 & 40.04 & 36.92 & 7.73 & 7.47 & 50.20 & 37.92 & 33.87 \\
\hline 16. & Mizoram & 52.67 & 45.01 & 40.04 & 36.92 & 7.73 & 7.47 & 50.32 & 25.66 & 19.47 \\
\hline 17. & Nagaland & 52.67 & 45.01 & 40.04 & 36.92 & 7.73 & 7.47 & 50.81 & 37.92 & 32.67 \\
\hline 18. & Orissa & 67.28 & 49.72 & 48.01 & 55.62 & 41.64 & 42.83 & 66.18 & 48.56 & 47.15 \\
\hline 19. & Punjab & 28.21 & 11.95 & 6.35 & 27.96 & 11.35 & 5.75 & 28.15 & 11.77 & 6.16 \\
\hline 20. & Rajasthan & 44.76 & 26.46 & 13.74 & 52.13 & 30.49 & 19.85 & 46.14 & 27.41 & 15.28 \\
\hline 21. & Sikkim & 52.67 & 45.01 & 40.04 & 36.92 & 7.73 & 7.47 & 50.86 & 41.43 & 36.55 \\
\hline 22. & Tamil Nadu & 57.43 & 32.48 & 20.55 & 49.40 & 39.77 & 22.11 & 54.94 & 35.03 & 21.12 \\
\hline 23. & Tripura & 52.67 & 45.01 & 40.04 & 36.92 & 7.73 & 7.47 & 51.00 & 39.01 & 34.44 \\
\hline 24. & Uttar Pradesh & 56.53 & 42.28 & 31.22 & 60.09 & 35.39 & 30.89 & 57.07 & 40.85 & 31.15 \\
\hline 25 . & West Bengal & 73.16 & 40.80 & 31.85 & 34.67 & 22.41 & 14.86 & 63.43 & 35.66 & 27.02 \\
\hline 26. & A \& N Island & 57.43 & 32.48 & 20.55 & 49.60 & 39.77 & 22.11 & 55.56 & 34.47 & 20.99 \\
\hline 27. & Chandigarh & 27.96 & 11.35 & 5.75 & 27.96 & 11.35 & 5.75 & 27.96 & 11.35 & 5.75 \\
\hline 28. & Dadra \& Nagar Hav. & 46.85 & 51.95 & 17.57 & 37.69 & 39.93 & 13.52 & 46.55 & 50.84 & 17.14 \\
\hline 29. & Daman \& Diu & N.A. & 5.34 & 1.35 & N.A. & 27.03 & 7.52 & N.A. & 15.80 & 4.44 \\
\hline 30. & Delhi & 24.44 & 1.90 & 0.40 & 52.23 & 16.03 & 9.42 & 49.61 & 14.69 & 8.23 \\
\hline 31. & Lakshadweep & 59.19 & 25.76 & 9.38 & 62.74 & 24.55 & 20.27 & 59.68 & 25.04 & 15.60 \\
\hline \multirow[t]{2}{*}{32.} & Pondicherry & 57.43 & 32.48 & 20.55 & 49.40 & 39.77 & 22.11 & 53.82 & 37.40 & 21.67 \\
\hline & All India & 56.44 & 37.27 & 27.09 & 49.01 & 32.36 & 23.62 & 54.88 & 35.97 & 26.10 \\
\hline \multicolumn{11}{|c|}{ N.A. Not Available } \\
\hline & \multirow{3}{*}{\multicolumn{10}{|c|}{$\begin{array}{l}\text { Poverty Ratio of Assam is used for Sikkim, Arunachal Pradesh, Meghalaya, Mizoram, Manipur, Nagaland and Tripura. } \\
\text { Poverty Line of Maharashtra and expenditure distribution of Goa is used to estimate poverty ratio of Goa. } \\
\text { Poverty Line of Himachal Pradesh and expenditure distribution of Jammu \& Kashmir is used to estimate poverty ratio of } \\
\text { Jammu \& Kashmir. }\end{array}$}} \\
\hline & & & & & & & & & & \\
\hline & & & & & & & & & & \\
\hline & \multicolumn{10}{|c|}{ Poverty Ratio of Tamil Nadu is used for Pondicherry and A \& N Island } \\
\hline & \multicolumn{10}{|c|}{ Urban Poverty Ratio of Punjab used for both rural and urban poverty of Chandigarh } \\
\hline & \multicolumn{10}{|c|}{ Poverty Line of Maharashtra and expenditure of Dadra \& Nagar Haveli is used to estimate poverty ratio of } \\
\hline & \multicolumn{10}{|c|}{ Poverty Ratio of Goa is used for Daman \& Diu. } \\
\hline & \multicolumn{10}{|c|}{ Poverty Ratio of Kerala is used for Lakshadweep. } \\
\hline & \multicolumn{10}{|c|}{ Urban Poverty Ratio of Rajasthan may be treated as tentative. } \\
\hline & \multicolumn{10}{|c|}{ Estimates on a 30-day recall basis for $1999-2000$. } \\
\hline \multicolumn{11}{|c|}{ Source: Planning Commission, Government of India, New Delhi. } \\
\hline
\end{tabular}

